medRxiv preprint doi: https://doi.org/10.1101/2021.08.31.21262944; this version posted September 2,2021 . The copyright holder for this preprint (which was not certified by peer review) is the author/funder, who has granted medRxiv a license to display the preprint in It is made available under a CC-BY 4.0 International license .

\title{
Estimating salt consumption in 49 low- and middle-income countries: Development, validation and application of a machine learning model
}

Wilmer Cristobal Guzman-Vilca ${ }^{1,2,3}$

Manuel Castillo-Cara ${ }^{4}$

Rodrigo M. Carrillo-Larco ${ }^{2,5}$

1. School of Medicine "Alberto Hurtado", Universidad Peruana Cayetano Heredia, Lima, Peru.

2. CRONICAS Centre of Excellence in Chronic Diseases, Universidad Peruana Cayetano Heredia, Lima, Peru.

3. Sociedad Científica de Estudiantes de Medicina Cayetano Heredia (SOCEMCH), Universidad Peruana Cayetano Heredia, Lima, Peru.

4. Universidad de Lima, Lima, Peru.

5. Department of Epidemiology and Biostatistics, School of Public Health, Imperial College London, London, UK.

\section{Correspondence author:}

Rodrigo M Carrillo-Larco, MD

Department of Epidemiology and Biostatistics

School of Public Health

Imperial College London

rcarrill@ic.ac.uk

Conflict of interest: None to declare.

Contributions: All authors conceived the idea. MC-C conducted the analysis with support from WCG-V and RMC-L. WCG-V drafted the manuscript with support from MC-C and RMC-L. All 
medRxiv preprint doi: https://doi.org/10.1101/2021.08.31.21262944; this version posted September 2,2021 . The copyright holder for this preprint (which was not certified by peer review) is the author/funder, who has granted medRxiv a license to display the preprint in It is made available under a CC-BY 4.0 International license.

\section{ABSTRACT}

Background: Global targets to reduce salt intake have been proposed but their monitoring is challenged by the lack of population-based data on salt consumption. We developed a machine learning (ML) model to predict salt consumption based on simple predictors, and applied this model to national surveys in low- and middle-income countries (LMICs).

Methods: Pooled analysis of WHO STEPS surveys. We used 19 surveys with spot urine samples for the ML model derivation and validation; we developed a supervised ML regression model based on: sex, age, weight, height, systolic and diastolic blood pressure. We applied the ML model to 49 new STEPS surveys to quantify the mean salt consumption in the population.

Results: The pooled dataset in which we developed the ML model included 45,152 people. Overall, there were no substantial differences between the observed ( $8.1 \mathrm{~g} /$ day $(95 \% \mathrm{Cl}: 8.0-8.2$ g/day)) and ML-predicted (8.1 g/day (95\% Cl: 8.1-8.2 g/day)) mean salt intake $(p=0.065)$. The pooled dataset where we applied the ML model included 157,699 people; the overall predicted mean salt consumption was $8.1 \mathrm{~g} / \mathrm{day}(95 \% \mathrm{Cl}: 8.1-8.2 \mathrm{~g} / \mathrm{day})$. The countries with the highest predicted mean salt intake were in Western Pacific. The lowest predicted intake was found in Africa. The country-specific predicted mean salt intake was within reasonable difference from the best available evidence.

Conclusions: A ML model based on readily available predictors estimated daily salt consumption with good accuracy. This model could be used to predict mean salt consumption in the general population where urine samples are not available.

Funding: Wellcome Trust (214185/Z/18/Z)

Key words: artificial intelligence; deep learning; cardio-metabolic risk factors; cardiovascular health; global health; population health. 
medRxiv preprint doi: https://doi.org/10.1101/2021.08.31.21262944; this version posted September 2,2021 . The copyright holder for this preprint (which was not certified by peer review) is the author/funder, who has granted medRxiv a license to display the preprint in It is made available under a CC-BY 4.0 International license.

\section{INTRODUCTION}

The association between high sodium/salt intake and high blood pressure, a major risk factor of cardiovascular diseases (CVD), is well-established. ${ }^{1-3}$ More than 1.7 million CVD deaths were attributed to a diet high in sodium in 2019 , with $\sim 90 \%$ of these deaths occurring in low- and middleincome countries (LMICs). ${ }^{4,5}$ Consequently, salt reduction has been included in international goals: the World Health Organization (WHO) recommendation of limiting salt consumption to $<5$ $\mathrm{g} / \mathrm{day},{ }^{2}$ and the agreement by the WHO state members of a $30 \%$ relative reduction in mean population salt intake by $2025 .^{6}$ Because available evidence suggests that sodium/salt consumption is higher than the global targets, ${ }^{7-9}$ we need timely and consistent data of sodium/salt consumption in the general population to track progress of salt reduction targets.

Global efforts have been made to produce comparable estimates of sodium/salt intake for all countries. ${ }^{7}$ Similarly, researchers have summarized all the available evidence in specific world regions ${ }^{8,9}$ Although the global endeavor was based on the gold standard method to assess sodium/salt intake (i.e., 24-hour urine sample), their estimates were up to $2010 .{ }^{7}$ Therefore, robust and comparable sodium/salt intake estimates for all countries lack for the last ten years. The regional endeavors summarized population-based evidence, yet they conducted study-level meta-analyses in which the original studies could have followed different laboratory methods, and they did not study all countries in the region. Therefore, comparability across studies could be limited and evidence lacks for many countries. Finding a method to estimate sodium/salt consumption in national samples leveraging on available data is needed to update and complement the existing evidence. ${ }^{7-10}$ However, quantifying sodium/salt intake based on 24 -hour urine samples is costly and burdensome, limiting its use in population-based studies or national health surveys. As an alternative, equations have been developed to estimate sodium/salt intake based on spot urine (SU) samples. ${ }^{11-14}$ However, these equations have been used in few WHO STEPS and other national health surveys ${ }^{15}$ leaving several countries without data to quantify the local sodium/salt consumption because they do not have access to SU samples. ${ }^{16}$

If we could (accurately) estimate sodium/salt intake based on variables that are routinely available in national health surveys (e.g., weight or blood pressure), mean sodium/salt intake in countries 
medRxiv preprint doi: https://doi.org/10.1101/2021.08.31.21262944; this version posted September 2, 2021. The copyright holder for this preprint (which was not certified by peer review) is the author/funder, who has granted medRxiv a license to display the preprint in It is made available under a CC-BY 4.0 International license.

that currently lack urine data (i.e., 24-hour or spot) could be computed using these available predictors. Advanced analytic techniques like machine learning (ML) could make accurate predictions, and inform about the population sodium/salt intake in LMICs. We developed a ML predictive model to estimate salt intake using routinely available variables in WHO STEPS surveys, and we applied this ML model to WHO STEPS surveys without urine data to compute the mean salt intake in the general population.

\section{METHODS}

\section{Study design}

This is a data pooling ML analysis of individual-level data of WHO STEPS surveys. First, we downloaded 19 WHO STEPS surveys with SU samples; these surveys were used for the training, validation and testing the ML model. These 19 WHO STEPS surveys represented 17 LMICs; two countries contributed with two surveys: Bhutan 2014 and 2019 as well as Mongolia 2013 and 2019. Second, we downloaded 49 new WHO STEPS surveys which had the variables included in the ML prediction model (see Variables section), but did not have SU samples. The ML model herein developed was applied to these 49 surveys to estimate the mean salt consumption in the population. All WHO STEPS surveys herein analysed were national (i.e., sub-national surveys were excluded).

\section{Rationale}

We hypothesized that a ML model could accurately predict salt consumption at the individual level, to then inform the overall mean in the underlying population. In addition, we endeavoured to develop a ML model with simple predictors; that is, variables that are routinely available in national health surveys contrary to urine sample that are seldom collected in national health surveys in LMICs. If the model were indeed accurate, then it could be applied to national surveys without urine samples but with the relevant predictors to inform about the mean salt consumption in the target population. These model-driven estimates could be preliminary, until a national health survey is conducted to study mean salt consumption with urine samples (ideally 24-hour urine samples). 
medRxiv preprint doi: https://doi.org/10.1101/2021.08.31.21262944; this version posted September 2,2021 . The copyright holder for this preprint (which was not certified by peer review) is the author/funder, who has granted medRxiv a license to display the preprint in It is made available under a CC-BY 4.0 International license.

\section{Variables}

The predictors we used in the ML model were: sex, age (years), weight $(\mathrm{kg})$, height $(\mathrm{m})$, systolic blood pressure (SBP, $\mathrm{mmHg}$ ) and diastolic blood pressure (DBP, $\mathrm{mmHg}$ ).

The WHO STEPS surveys collect anthropometric and three blood pressure measurements. These are taken by trained fieldworkers following a standard protocol. ${ }^{15}$ We used measured weight and height to compute the body mass index $\left(\mathrm{BMI}, \mathrm{kg} / \mathrm{m}^{2}\right)$. We used the mean SBP and mean DBP of the second and third blood pressure measurements (i.e., the first blood pressure measurement was discarded).

The outcome was salt intake as per the INTERSALT equation. ${ }^{11}$ We chose this equation because it has been used by some WHO STEPS surveys. There is a specific INTERSALT equation for each sex, and they both include the following variables: age (years), BMI $\left(\mathrm{kg} / \mathrm{m}^{2}\right)$, SU sodium $(\mathrm{mmol} / \mathrm{L})$, and SU creatinine $(\mathrm{mmol} / \mathrm{L}) .{ }^{11}$ We used the following sex-specific formulas.

$$
\begin{gathered}
\text { Men: }\left\{23.51+\left[0.45 \times N a_{S U}\right]-\left[3.09 \times C r_{S U}\right]+[4.16 \times \mathrm{BMI}]+[0.22 \times \text { age }]\right\} \\
\text { Women: }\left\{3.74+\left[0.33 \times N a_{S U}\right]-\left[2.44 \times C r_{S U}\right]+[2.42 \times B M I]+[2.34 \times \text { age }]-\left[0.03 \times \mathrm{age}^{2}\right]\right\}
\end{gathered}
$$

Where the subscript $S U$ indicates spot urine, $\mathrm{Na}$ is sodium, $\mathrm{Cr}$ is creatinine and $\mathrm{BMI}$ is body mass index. Because some STEPS surveys had SU creatinine in $\mathrm{mg} / \mathrm{dl}$, these values were multiplied by 0.00884 to obtain SU creatinine in mmol/L. No conversion was needed for sodium in $\mathrm{SU}$ samples because all WHO STEPS surveys herein included already had urinary sodium in mmol/L. The INTERSALT equation computes 24-hour sodium intake, which is then divided by 17.1 to obtain the salt intake in grams per day $(\mathrm{g} / \mathrm{d}) .{ }^{11}$ For descriptive purposes, we also computed salt intake based on the Kawasaki, ${ }^{12}$ Toft $^{13}$ and Tanaka ${ }^{14}$ equations.

\section{Analysis}

\section{Data preparation}

Our complete-case analysis was restricted to men and non-pregnant women aged between 15 and 69 years. We dropped participants with implausible BMI levels (outside the range 10-80 
medRxiv preprint doi: https://doi.org/10.1101/2021.08.31.21262944; this version posted September 2,2021 . The copyright holder for this preprint (which was not certified by peer review) is the author/funder, who has granted medRxiv a license to display the preprint in It is made available under a CC-BY 4.0 International license.

$\mathrm{kg} / \mathrm{m}^{2}$ ) or with implausible weight (outside the range 12-300 $\mathrm{kg}$ ) or height records (outside the range 1.00-2.50 m). Participants with SBP outside the range $70-270 \mathrm{mmHg}$ were discarded, and so were participants with DBP outside the range $30-150 \mathrm{mmHg}$. We excluded records with SU creatinine $<1.8$ or $>32.7 \mathrm{mmol} / \mathrm{L}$ for males and $<1.8$ or $>28.3$ for females. ${ }^{17,18}$ In addition, we excluded participants with estimated salt intake (using the 4 equations) above or below three standard deviations from the equation-specific mean (Supplementary Figure 1). ${ }^{19}$ After completing data preparation, observations were randomly assigned from the pooled dataset $(100 \%)$ into three datasets for the $\mathrm{ML}$ analysis: training data (50\%), test data $(30 \%)$ and validation data $(20 \%)$.

\section{Machine learning modelling}

Our research aim was a regression problem where we had a known outcome attribute (salt consumption at the subject level). Therefore, we planned a supervised ML regression analysis. Details about the modelling process are available in the Extended Methods (Supplementary Material pp. 03-06). In brief, we designed a work pipeline with five steps. First, data analysis, where we dropped missing observations, we explored the available data to choose scaling and transformation methods to secure all variables were in the same scale or units, and we also planned transformations for categorical variables (e.g., one-hot encoding). Second, feature importance analysis, where we investigated the contribution of each predictor to the regression model through methods like Random Forest and Recursive Feature Elimination. The aim of this second step was to exclude any predictor that would not contribute to the regression model. Notably, all predictors (see Variables section) chosen following expert knowledge were kept in the analysis (i.e., the feature importance analysis did not suggest the exclusion of any predictor). Third, data processing, having explored the available data (first step in the work pipeline), we implemented different scaling and transformation methods (e.g., Box-Cox, Principal Component Analysis and polynomial features). Fourth, data modelling, where we implemented ten $\mathrm{ML}$ algorithms: i) Linear Regression (LiR); ii) Hubber Regressor (HuR); iii) Ridge Regressor (RiR); iv) Multilayer Perceptron (MLP); v) Support Vector Regressor (SVR); vi) $k$-Nearest Neighbors (KNN); vii) Random Forest (RF); viii) Gradient Boost Machine (GBM); ix) Extreme Gradient Boosting (XBG); and $\mathrm{x}$ ) a customized neural network. All these $\mathrm{ML}$ algorithms performed similarly, so the 
medRxiv preprint doi: https://doi.org/10.1101/2021.08.31.21262944; this version posted September 2,2021 . The copyright holder for this preprint (which was not certified by peer review) is the author/funder, who has granted medRxiv a license to display the preprint in It is made available under a CC-BY 4.0 International license.

decision to choose one was postponed to the fifth (last) step in the work pipeline. Up to this point, we used the training and validations datasets. Five, forecasting of the predicted attribute in new data (i.e., data not used for model training); in this step we used the test dataset to choose the model that yielded predictions closest to the observed salt intake. Results comparing the observed and the predicted salt intake were computed in the test dataset alone. For each country we ran a paired t-test between the observed and predicted salt consumption, where a difference was deemed significant at a $p<0.05$. We also computed the absolute difference between the observed and predicted salt intake. We chose the RF algorithm because it showed the mean difference closest to zero in both sexes combined (observed - predicted $=0)($ Supplementary table 1 , Supplementary figure 2). All summary estimates (e.g., mean salt intake) were computed accounting for the complex survey design of the WHO STEPS surveys.

\section{Application of the developed ML model}

Having developed the ML model following the steps above described, we applied the model to 49 WHO STEPS national surveys which did not have urine samples but included the predictors in the ML model (see Variables section). In each of these 49 surveys we computed the mean daily salt intake accounting for the complex survey design. These surveys were pre-processed following the same procedures described in the Data preparation section.

\section{Ethics}

We did not seek approval by an Institutional Review Board. We used individual-level survey data which do not include any personal identifiers.

\section{Role of the funding source}

The funder had no role in the study design, analysis, interpretation or decision to publish. The authors are collectively responsible for the accuracy of the data. The arguments and opinions in this work are those of the authors alone, and do not represent the position of the institutions to which they belong. 
medRxiv preprint doi: https://doi.org/10.1101/2021.08.31.21262944; this version posted September 2,2021 . The copyright holder for this preprint (which was not certified by peer review) is the author/funder, who has granted medRxiv a license to display the preprint in It is made available under a CC-BY 4.0 International license.

\section{RESULTS}

\section{Study population for model derivation and validation}

The pooled dataset included 45,152 people from 17 LMICs in 19 WHO STEPS surveys (i.e., two countries, Bhutan and Mongolia, had 2 surveys) conducted between 2013-2019 (Supplementary table 2). Overall, the mean age was 38.6 (95\% confidence interval $(95 \% \mathrm{Cl}): 38.1-39.0)$ years and the proportion of women was $52.1 \%$. The mean SBP was $122.0 \mathrm{mmHg}(95 \% \mathrm{Cl}: 121.4-122.6$ $\mathrm{mmHg}$ ) and mean DBP was $79.2 \mathrm{mmHg}(95 \% \mathrm{Cl}: 78.8-79.6 \mathrm{mmHg})$. The mean weight was 59.2 $\mathrm{kg}(95 \% \mathrm{Cl}: 58.8-59.7 \mathrm{~kg})$ and the mean height was $1.59 \mathrm{~m}$ (95\% Cl: $1.58-1.59 \mathrm{~m})$.

\section{Observed and predicted mean salt intake during the ML model derivation and validation}

In the test dataset including 19 WHO STEPS surveys, the observed mean salt intake computed as per the INTERSALT equation was $8.1 \mathrm{~g} /$ day (95\% Cl: 8.0-8.2 g/day) across countries. The observed salt intake was higher in men $(8.9 \mathrm{~g} /$ day; $95 \% \mathrm{Cl}: 8.7-9.0 \mathrm{~g} /$ day) than in women $(7.4$ g/day; $95 \% \mathrm{Cl}: 7.3-7.4 \mathrm{~g} /$ day). Across countries, the predicted mean salt intake was $8.1 \mathrm{~g} / \mathrm{day}$ (95\% Cl: 8.1-8.2 g/day). Men had a higher predicted mean salt intake (8.9 g/day; 95\% Cl: 8.8-8.9 g/day) than women $(7.4 \mathrm{~g} /$ day; $95 \% \mathrm{Cl}: 7.4-7.5 \mathrm{~g} /$ day). Overall, there were no substantial differences between the observed and predicted estimates $(p=0.065)$. Results for each survey are presented in Figure 1 and Supplementary table 3.

In men across all countries in the test dataset including 19 WHO STEPS surveys representing 17 LMICs, the mean difference between observed and predicted mean salt intake was $0.02 \mathrm{~g} /$ day $(p=0.277)$. Across all surveys, the positive mean difference farthest from zero was $1.39 \mathrm{~g} / \mathrm{day}$ (Malawi, $\mathrm{p}<0.001$ ), and the negative mean difference farthest from zero was $-0.74 \mathrm{~g} /$ day (Lebanon, $p=0.227$ ). The mean difference closest to zero was $0.03 \mathrm{~g} /$ day (Armenia, $p=0.787$ ) (Supplementary table 4).

In women across all countries in the test dataset including 19 WHO STEPS surveys representing 17 LMICs, the mean difference between the observed and predicted mean salt intake was -0.02 $\mathrm{g} /$ day $(p=0.124)$. The positive mean difference farthest from zero was $1.02 \mathrm{~g} /$ day (Malawi, $\mathrm{p}<0.001$ ) and the negative mean difference farthest from zero was in $-0.71 \mathrm{~g} /$ day (Brunei 
medRxiv preprint doi: https://doi.org/10.1101/2021.08.31.21262944; this version posted September 2, 2021. The copyright holder for this preprint (which was not certified by peer review) is the author/funder, who has granted medRxiv a license to display the preprint in It is made available under a CC-BY 4.0 International license.

Darussalam, $p<0.001)$. The mean difference closest to zero was $-0.07 \mathrm{~g} / \mathrm{day}($ Armenia, $p=0.343$ ) (Supplementary table 4).

None of the LMICs herein analysed, regardless of the method of sodium intake assessment (i.e., observed or predicted), showed a mean salt intake below the $\mathrm{WHO}$ recommended level of $<5$ g/day (Figure 1, Supplementary table 3). The same occurred for the mean salt intake estimates using the Kawasaki, Toft and Tanaka formulas (Supplementary table 5).

\section{Implementation of the developed ML model to predict salt consumption in 49 LMICs}

The pooled dataset where we applied the ML model included 157,699 people from 49 LMICs in 49 WHO STEPS surveys conducted between 2004-2018 (Supplementary table 6). Overall, the mean age was 37.7 (95\% Cl: $37.2-38.1)$ years and the proportion of women was $48.8 \%$. The mean SBP was $123.8 \mathrm{mmHg}(95 \% \mathrm{Cl}: 123.1-124.4 \mathrm{mmHg})$ and mean DBP was $79.1 \mathrm{mmHg}(95 \%$ $\mathrm{Cl}: 78.7-79.6 \mathrm{mmHg})$. The mean weight was $60.6 \mathrm{~kg}(95 \% \mathrm{Cl}: 60.2-61.0 \mathrm{~kg})$ and the mean height was $1.61 \mathrm{~m}(95 \% \mathrm{Cl}: 1.61-1.61 \mathrm{~m})$.

Across the $49 \mathrm{LMICs}$, the predicted mean salt intake was $8.1 \mathrm{~g} / \mathrm{day}(95 \% \mathrm{Cl}: 8.1-8.2 \mathrm{~g} / \mathrm{day})$, and it was higher in men $(8.9 \mathrm{~g} / \mathrm{day} ; 95 \% \mathrm{Cl}: 8.8-8.9 \mathrm{~g} /$ day $)$ than in women $(7.4 \mathrm{~g} / \mathrm{day}$; $95 \% \mathrm{Cl}$ : $7.3-$ $7.4 \mathrm{~g} /$ day). None of the LMICs herein analysed, regardless of sex, showed a predicted mean salt intake below the WHO recommended level of $<5 \mathrm{~g} /$ day (Figure 2, Supplementary table 7 ).

In men, the countries with the highest predicted mean salt intakes were Nauru and American Samoa (both with $11.1 \mathrm{~g} / \mathrm{day})$, Cook Islands (11.0 g/day) and Niue (10.7 g/day); remarkably, three of these countries (Nauru, Cook Islands and Niue) are in Western Pacific. In contrast, the lowest predicted mean salt intake in men were in Ethiopia ( $8.3 \mathrm{~g} /$ day), Eritrea and Timor-Leste (both with $8.4 \mathrm{~g} / \mathrm{day}$ ), and United Republic of Tanzania, Botswana and Uganda (all with $8.6 \mathrm{~g} / \mathrm{day}$ ); remarkably, all of these countries except Timor-Leste are in Africa.

In women, the countries with the highest predicted mean salt intakes were American Samoa (9.0 g/day), Nauru ( $8.8 \mathrm{~g} /$ day), and Cook Islands, Samoa and Tuvalu (all with $8.6 \mathrm{~g} /$ day); the latter four 
medRxiv preprint doi: https://doi.org/10.1101/2021.08.31.21262944; this version posted September 2,2021 . The copyright holder for this preprint (which was not certified by peer review) is the author/funder, who has granted medRxiv a license to display the preprint in It is made available under a CC-BY 4.0 International license.

countries are in Western Pacific. Conversely, the lowest predicted mean salt intake in women were in Ethiopia and Eritrea (both with $6.9 \mathrm{~g} /$ day), Timor-Leste ( $7.0 \mathrm{~g} /$ day), and Vietnam $(7.1$ g/day); the first two countries (out of four) are in Africa.

\section{DISCUSSION}

\section{Main findings}

This work leveraged on 19 national health surveys and readily available predictors to develop a ML model to predict salt consumption; this model was then applied to national surveys in $\mathbf{4 9}$ LMICs. The RF ML algorithm yielded the predictions closest to the observed salt intake: the mean difference between predicted and observed salt consumption across surveys was $0.02 \mathrm{~g} /$ day in men and $-0.02 \mathrm{~g} /$ day in women. We used this novel ML model to predict salt consumption in 49 LMICs, where the mean salt consumption ranged from $8.3 \mathrm{~g} /$ day (Ethiopia) to $11.1 \mathrm{~g} /$ day (Nauru) in men; these numbers in women ranged from $6.9 \mathrm{~g} /$ day (Ethiopia and Eritrea) to $9.0 \mathrm{~g} / \mathrm{day}$ (American Samoa). This work aimed to elaborate on novel analytical tools to predict salt consumption where national surveys have not collected this information limiting their ability to keep track of mean sodium consumption in the general population. Pending external independent validation, our model could be used in monitoring frameworks of salt consumption because most countries do not collect sodium samples in their national health surveys. Our model could contribute to the global surveillance of salt consumption, a relevant cardio-metabolic risk factor. ${ }^{1-}$

\section{Public health implications}

ML models have been used extensively to predict relevant clinical outcomes (e.g., mortality) and epidemiological indicators (e.g., forecasting COVID-19 cases). ${ }^{20-24}$ Furthermore, ML algorithms have proven to be useful for understanding complex outcomes (e.g., identifying clusters of people with diabetes) based on simple predictors (e.g., BMI) in nationally-representative survey data. ${ }^{25-}$ ${ }^{27}$ Our work complements the current evidence on ML algorithms by demonstrating its use in a relevant field: population salt consumption. In so doing, we delivered a pragmatic tool which could be used to inform the surveillance of salt consumption in countries where national surveys do not objectively collect this information (e.g., SU samples). Moreover, this work provided preliminary 
medRxiv preprint doi: https://doi.org/10.1101/2021.08.31.21262944; this version posted September 2,2021 . The copyright holder for this preprint (which was not certified by peer review) is the author/funder, who has granted medRxiv a license to display the preprint in It is made available under a CC-BY 4.0 International license.

evidence to update the global estimates of population-based sodium consumption, ${ }^{7}$ by informing about the mean sodium consumption in 49 LMICs. Our results suggest that mean salt consumption is above the WHO recommended level in all the 49 LMICs herein analysed, and it was the highest among LMICs in Western Pacific, and the lowest among LMICs in Africa. This finding, which is consistent with a global work, ${ }^{7}$ calls for urgent actions to reduce salt consumption in these 49 LMICs, especially those in Western Pacific.

We do not believe that our -or any other- ML model should replace a comprehensive populationbased nationally representative health survey with 24 -hour or spot urine samples. However, until such surveys are available in many LMICs and periodically conducted, we could suggest using an estimation approach to shed lights about the mean salt consumption in the population. Our ML model seems to be a reasonably good alternative, and could become a pragmatic tool for surveillance systems that keep track of sodium consumption in accordance with global goals. ${ }^{2,6}$

\section{Research in context}

A global effort provided mean sodium/salt consumption estimates for 187 countries in 1990 and $2010 ; ;^{7}$ they used 24-hour urine samples and dietary reports from surveys conducted in 66 countries, including LMICs. Unfortunately, their results were until 2010 and many LMICs were not included. Our results advanced this evidence by providing more recent salt consumption estimates, because most of the surveys in which we applied our ML model were conducted after 2010 (Supplementary table 6).

Compared to the global estimates for the same LMICs in $2010,{ }^{7}$ our mean salt consumption estimates were very similar. For example, our 2010 mean salt consumption estimates for Cambodia, Eritrea and the Gambia were $8.0 \mathrm{~g} /$ day, $7.2 \mathrm{~g} /$ day and $8.3 \mathrm{~g} /$ day, whereas the estimates by Powles et al. were $11.0 \mathrm{~g} /$ day, $5.9 \mathrm{~g} /$ day and $7.7 \mathrm{~g} /$ day (Supplementary table 8$){ }^{7}$ We further compared our estimates for surveys conducted between 2007 and $2013(+/-3$ years around 2010) with the 2010 estimates provided by Powles et al., ${ }^{7}$ and our results were also within reasonable difference. The largest differences were in Kyrgyzstan ( 8.7 by our ML model versus 13.4 by Powles et al..$\left.^{7}\right)$, as well as in Comoros $\left(8.4\right.$ versus $\left.4.2^{7}\right)$ and Rwanda ( 8.0 versus $\left.4.0^{7}\right)$. It 
medRxiv preprint doi: https://doi.org/10.1101/2021.08.31.21262944; this version posted September 2,2021 . The copyright holder for this preprint (which was not certified by peer review) is the author/funder, who has granted medRxiv a license to display the preprint in It is made available under a CC-BY 4.0 International license.

appears that our predictions were higher than those provided by Powles et al. ${ }^{7}$ in countries with presumably low salt consumption (e.g., Comoros, Rwanda); conversely, in countries with presumably high salt consumption (e.g., Kyrgyzstan), our predictions revealed smaller estimates than those by Powles et al. ${ }^{7}$ (Supplementary table 8). These differences could be explained by the fact that our ML model was developed based on SU samples rather than 24-hour urine samples as Powles et al. did. Strong evidence indicates that estimates based on SU may overestimate salt intake at lower levels of consumption and underestimate salt intake at higher levels of consumption. ${ }^{28}$

In addition to the global work by Powles et al., ${ }^{7}$ there are other reports from some specific LMICs. For example, a survey conducted between 2012 and 2016 with 24-hour urine samples in Fiji and Samoa showed that the mean salt consumption was $10.6 \mathrm{~g} /$ day and $7.1 \mathrm{~g} /$ day, respectively. ${ }^{17}$ The estimates from our ML model for Fiji (2011) and Samoa (2013) suggested that the mean salt consumption was $8.9 \mathrm{~g} /$ day and $9.6 \mathrm{~g} / \mathrm{day}$, respectively. A survey in Vanuatu in 2016 based on 24-hour urine sample informed that the mean salt intake was $5.9 \mathrm{~g} / \mathrm{day} ;{ }^{18}$ our estimate for the year 2011 was $8.6 \mathrm{~g} /$ day. In 2009 in Vietnam a survey with SU samples revealed that the mean salt consumption was $9.9 \mathrm{~g} / \mathrm{day} ;{ }^{19}$ our prediction for the year 2015 was 7.9. These comparisons suggest that our ML-predicted estimates are plausible and close to the best available evidence.

Although these comparisons do not validate our predictions in the 49 national surveys, they suggest that our salt consumption estimates are within reasonable distance from the best available evidence. Until better data are available (e.g., national survey with spot or 24-hour urine sample), our model could provide preliminary evidence to inform the national mean salt consumption. Careful interpretation is warranted to understand the strengths and limitations of our ML-based predictions.

\section{Strengths and limitations}

We followed sound and transparent methods to develop a ML model to predict salt consumption at the individual level. We leveraged on open-access national data collected following standard and consistent protocols (WHO STEPS surveys). Most of the surveys we analysed were 
medRxiv preprint doi: https://doi.org/10.1101/2021.08.31.21262944; this version posted September 2,2021 . The copyright holder for this preprint (which was not certified by peer review) is the author/funder, who has granted medRxiv a license to display the preprint in It is made available under a CC-BY 4.0 International license.

conducted after 2010, providing more recent evidence than the latest global effort to quantify salt consumption in all countries. ${ }^{7}$ Notwithstanding, we must acknowledge some limitations. First, urine data was based on a spot sample, which is not the gold standard (24-hour urine sample) to measure daily salt consumption. Future work should verify and advance our results using on 24hour urine samples available in nationally representative samples; in the meantime, our work has led the foundations and hopefully sparked interest to use available data and novel analytical techniques to deliver estimates of salt consumption in the general population. Second, even though we analysed 19 national surveys (representing 17 LMICs) to develop our ML model, the sample size could still be limited for a data-driven ML algorithm (i.e., 22,577 observations were included in model development). A larger and global work in which all relevant data sources are pooled is needed; while this endeavour takes place, our work has provided recent estimates of salt consumption at the population level in 49 LMICs. In this line, there are still countries which were not herein included. Researchers in these countries, along with local (e.g., ministries of health) and international health authorities (e.g., WHO), should conduct studies/surveys to collect data on salt consumption. This would inform global targets but also local needs and interventions.

\section{Conclusions}

A ML model based on readily available variables was accurate to predict daily salt consumption. This ML model applied to 49 national surveys with no urine samples to compute daily salt consumption, revealed high levels of salt intake particularly in the Western Pacific region. Pending further validation, this ML model could be used to keep track of the overall sodium consumption where resources are not available to conduct national surveys with urine samples. 
medRxiv preprint doi: https://doi.org/10.1101/2021.08.31.21262944; this version posted September 2, 2021. The copyright holder for this preprint (which was not certified by peer review) is the author/funder, who has granted medRxiv a license to display the preprint in It is made available under a CC-BY 4.0 International license.

\section{DATA SHARING STATEMENT}

This study used nationally-representative survey data that are in the public domain, which was requested through the online repository (https://extranet.who.int/ncdsmicrodata/index.php/home). We provide the analysis code of data preparation and data analysis as supplementary materials to this paper. 
medRxiv preprint doi: https://doi.org/10.1101/2021.08.31.21262944; this version posted September 2, 2021. The copyright holder for this preprint (which was not certified by peer review) is the author/funder, who has granted medRxiv a license to display the preprint in It is made available under a CC-BY 4.0 International license.

\section{FIGURES}

Figure 1. Observed and predicted mean salt intake (g/day) by sex in each survey included in the ML model development

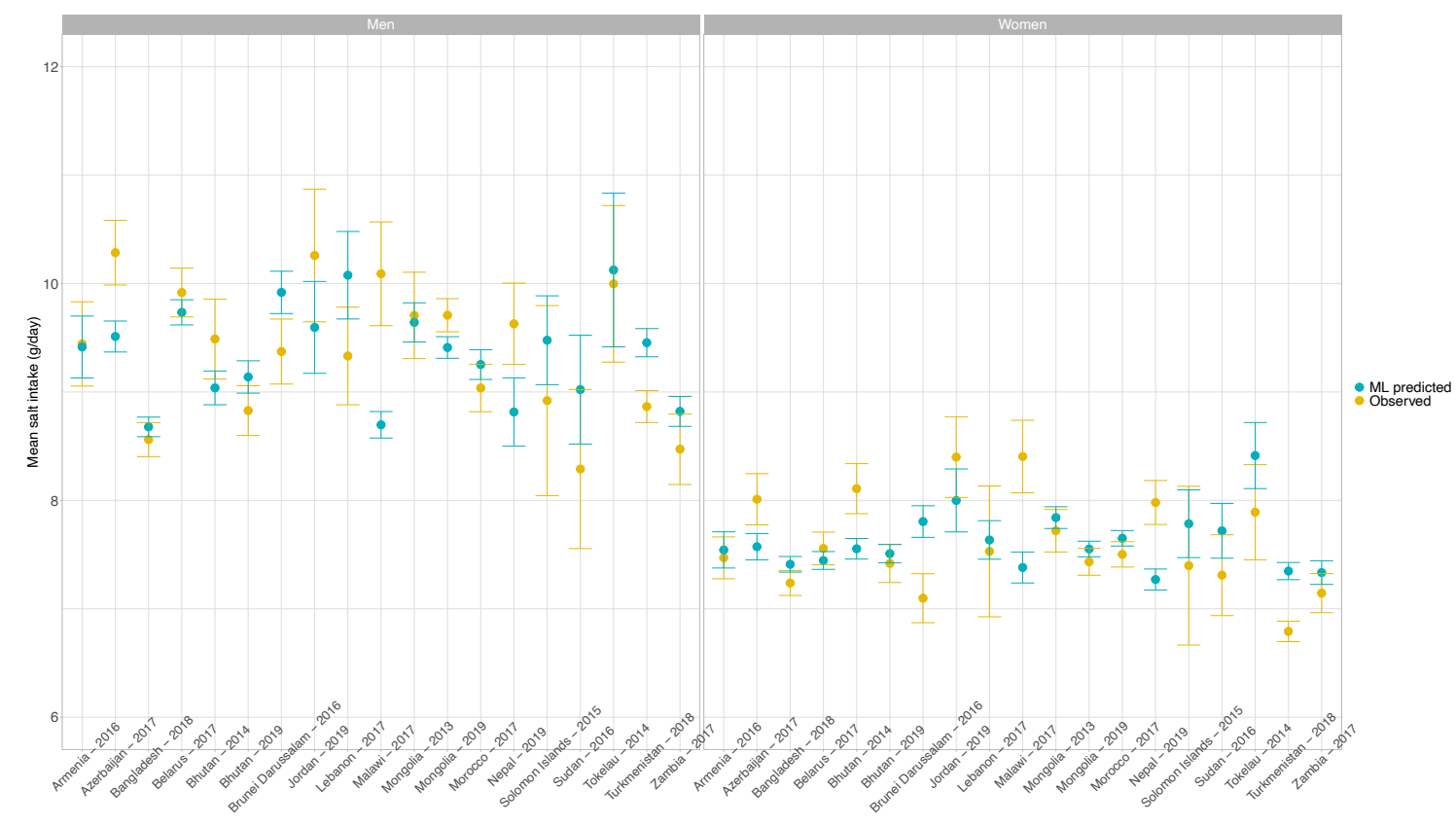

Exact estimates (along with their $95 \% \mathrm{Cl}$ ) are presented in Supplementary table 3 . These results were computed with the test dataset only. Results are for the Random Forest algorithm, which was the model with the best performance. 
medRxiv preprint doi: https://doi.org/10.1101/2021.08.31.21262944; this version posted September 2, 2021. The copyright holder for this preprint (which was not certified by peer review) is the author/funder, who has granted medRxiv a license to display the preprint in It is made available under a CC-BY 4.0 International license.

Figure 2. Predicted mean salt intake ( $g / d a y$ ) by sex in each of the 49 national surveys included in the application of the model herein developed.

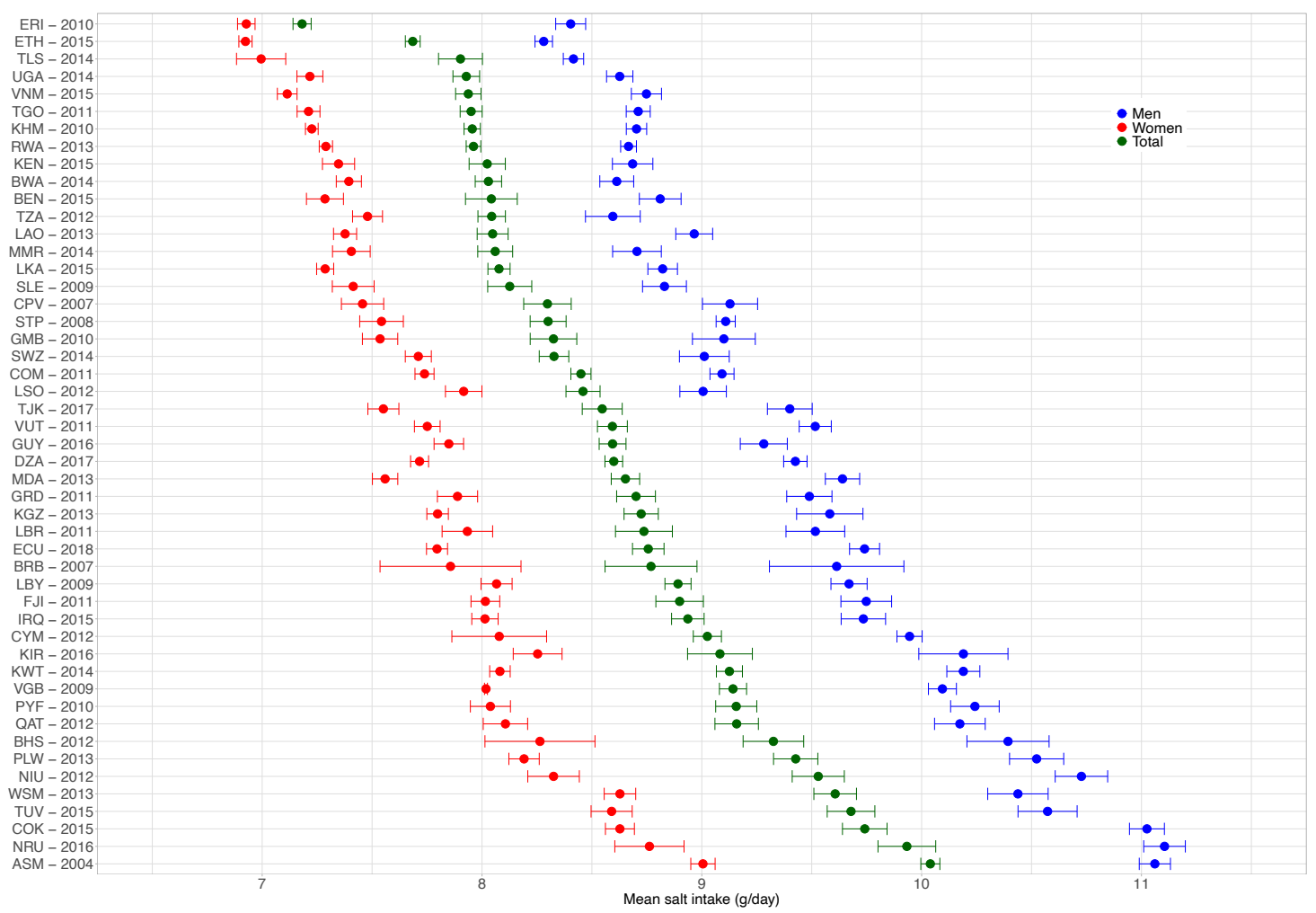

Exact estimates (along with their $95 \% \mathrm{Cl}$ ) are presented in Supplementary table 7 . Countries are presented in ascending order based on their overall mean salt intake (i.e., countries with the highest mean salt intake are at the bottom). 
medRxiv preprint doi: https://doi.org/10.1101/2021.08.31.21262944; this version posted September 2, 2021. The copyright holder for this preprint (which was not certified by peer review) is the author/funder, who has granted medRxiv a license to display the preprint in perpetuity.

It is made available under a CC-BY 4.0 International license .

\section{REFERENCES}

1. He FJ, Li J, Macgregor GA. Effect of longer term modest salt reduction on blood pressure: Cochrane systematic review and meta-analysis of randomised trials. BMJ. 2013 Apr 3;346:f1325.

2. World Health Organization. Salt reduction [Internet]. [cited 2021 Jun 6]. Available from: https://www.who.int/news-room/fact-sheets/detail/salt-reduction

3. Poggio R, Gutierrez L, Matta MG, Elorriaga N, Irazola V, Rubinstein A. Daily sodium consumption and CVD mortality in the general population: systematic review and metaanalysis of prospective studies. Public Health Nutr. 2015 Mar;18(4):695-704.

4. GBD 2019 Risk Factors Collaborators. Global burden of 87 risk factors in 204 countries and territories, 1990-2019: a systematic analysis for the Global Burden of Disease Study 2019. The Lancet. 2020 Oct 17;396(10258):1223-49.

5. GBD Results Tool | GHDx [Internet]. Available from: http://ghdx.healthdata.org/gbd-resultstool

6. World Health Organization. Population sodium reduction strategies [Internet]. WHO. World Health Organization; [cited 2021 Jun 6]. Available from: http://www.who.int/dietphysicalactivity/reducingsalt/en/

7. Powles J, Fahimi S, Micha R, Khatibzadeh S, Shi P, Ezzati M, et al. Global, regional and national sodium intakes in 1990 and 2010: a systematic analysis of $24 \mathrm{~h}$ urinary sodium excretion and dietary surveys worldwide. BMJ Open. 2013 Dec 23;3(12):e003733.

8. Carrillo-Larco RM, Bernabe-Ortiz A. Sodium and Salt Consumption in Latin America and the Caribbean: A Systematic-Review and Meta-Analysis of Population-Based Studies and Surveys. Nutrients. 2020 Feb 20;12(2).

9. Oyebode O, Oti S, Chen Y-F, Lilford RJ. Salt intakes in sub-Saharan Africa: a systematic review and meta-regression. Popul Health Metr. 2016;14:1.

10. Thout SR, Santos JA, McKenzie B, Trieu K, Johnson C, McLean R, et al. The Science of Salt: Updating the evidence on global estimates of salt intake. J Clin Hypertens (Greenwich). 2019 Jun;21(6):710-21.

11. Brown IJ, Dyer AR, Chan Q, Cogswell ME, Ueshima H, Stamler J, et al. Estimating 24-hour urinary sodium excretion from casual urinary sodium concentrations in Western populations: the INTERSALT study. Am J Epidemiol. 2013 Jun 1;177(11):1180-92.

12. Kawasaki T, Itoh $\mathrm{K}$, Uezono $\mathrm{K}$, Sasaki $\mathrm{H}$. A simple method for estimating $24 \mathrm{~h}$ urinary sodium and potassium excretion from second morning voiding urine specimen in adults. Clin Exp Pharmacol Physiol. 1993 Jan;20(1):7-14.

13. Toft $\mathrm{U}$, Cerqueira $\mathrm{C}$, Andreasen $\mathrm{AH}$, Thuesen $\mathrm{BH}$, Laurberg $\mathrm{P}$, Ovesen $\mathrm{L}$, et al. Estimating salt intake in a Caucasian population: can spot urine substitute 24-hour urine samples? Eur J Prev Cardiol. 2014 Oct;21(10):1300-7.

14. Tanaka $T$, Okamura $T$, Miura $\mathrm{K}$, Kadowaki $\mathrm{T}$, Ueshima $\mathrm{H}$, Nakagawa $\mathrm{H}$, et al. A simple method to estimate populational 24-h urinary sodium and potassium excretion using a casual urine specimen. J Hum Hypertens. 2002 Feb;16(2):97-103.

15. World Health Organization. STEPwise Approach to NCD Risk Factor Surveillance (STEPS) [Internet]. [cited 2021 Jun 6]. Available from: https://www.who.int/teams/noncommunicablediseases/surveillance/systems-tools/steps 
medRxiv preprint doi: https://doi.org/10.1101/2021.08.31.21262944; this version posted September 2, 2021. The copyright holder for this preprint (which was not certified by peer review) is the author/funder, who has granted medRxiv a license to display the preprint in perpetuity.

It is made available under a CC-BY 4.0 International license.

16. World Health Organization. NCD Microdata Repository [Internet]. [cited 2021 Jun 6]. Available from: https://extranet.who.int/ncdsmicrodata/index.php/catalog/STEPS

17. Santos JA, Rosewarne E, Hogendorf M, Trieu K, Pillay A, leremia M, et al. Estimating mean population salt intake in Fiji and Samoa using spot urine samples. Nutr J. 2019 Sep 10;18(1):55.

18. Paterson K, Hinge N, Sparks E, Trieu K, Santos JA, Tarivonda L, et al. Mean Dietary Salt Intake in Vanuatu: A Population Survey of 755 Participants on Efate Island. Nutrients. 2019 Apr 24;11(4).

19. Jensen PN, Bao TQ, Huong TTT, Heckbert SR, Fitzpatrick AL, LoGerfo JP, et al. The association of estimated salt intake with blood pressure in a Viet Nam national survey. PLoS One. 2018 Jan 18;13(1):e0191437.

20. Wang W, Kiik M, Peek N, Curcin V, Marshall IJ, Rudd AG, et al. A systematic review of machine learning models for predicting outcomes of stroke with structured data. PLoS One. 2020 Jun 12;15(6):e0234722.

21. Wynants L, Calster BV, Collins GS, Riley RD, Heinze G, Schuit E, et al. Prediction models for diagnosis and prognosis of covid-19: systematic review and critical appraisal. BMJ. 2020 Apr 7;369:m1328.

22. Groot OQ, Ogink PT, Lans A, Twining PK, Kapoor ND, DiGiovanni W, et al. Machine learning prediction models in orthopedic surgery: A systematic review in transparent reporting. J Orthop Res. 2021 Mar 18;

23. Watson GL, Xiong D, Zhang L, Zoller JA, Shamshoian J, Sundin P, et al. Pandemic velocity: Forecasting COVID-19 in the US with a machine learning \& Bayesian time series compartmental model. PLOS Computational Biology. 2021 Mar 29;17(3):e1008837.

24. Mohan S, A J, Abugabah A, M A, Kumar Singh S, Kashif Bashir A, et al. An approach to forecast impact of Covid-19 using supervised machine learning model. Softw Pract Exp. 2021 Apr 1;

25. Oh J, Yun K, Maoz U, Kim T-S, Chae J-H. Identifying depression in the National Health and Nutrition Examination Survey data using a deep learning algorithm. J Affect Disord. 2019 Oct 1;257:623-31.

26. García de la Garza Á, Blanco C, Olfson M, Wall MM. Identification of Suicide Attempt Risk Factors in a National US Survey Using Machine Learning. JAMA Psychiatry. 2021 Apr 1;78(4):398-406.

27. Carrillo-Larco RM, Castillo-Cara M, Anza-Ramirez C, Bernabé-Ortiz A. Clusters of people with type 2 diabetes in the general population: unsupervised machine learning approach using national surveys in Latin America and the Caribbean. BMJ Open Diabetes Res Care. 2021 Jan;9(1):e001889.

28. Huang L, Crino M, Wu JHY, Woodward M, Barzi F, Land M-A, et al. Mean population salt intake estimated from 24-h urine samples and spot urine samples: a systematic review and meta-analysis. Int J Epidemiol. 2016 Feb;45(1):239-50. 
medRxiv preprint doi: https://doi.org/10.1101/2021.08.31.21262944; this version posted September 2, 2021. The copyright holder for this preprint (which was not certified by peer review) is the author/funder, who has granted medRxiv a license to display the preprint in It is made available under a CC-BY 4.0 International license.

\section{SUPPLEMENTARY MATERIAL}

Estimating salt consumption in $\mathbf{4 9}$ low- and middle-income countries: Development, validation and application of a machine learning model

\section{Correspondence author:}

Rodrigo M Carrillo-Larco, MD

Department of Epidemiology and Biostatistics

School of Public Health

Imperial College London

rcarrill@ic.ac.uk 
medRxiv preprint doi: https://doi.org/10.1101/2021.08.31.21262944; this version posted September 2, 2021. The copyright holder for this preprint (which was not certified by peer review) is the author/funder, who has granted medRxiv a license to display the preprint in It is made available under a CC-BY 4.0 International license.

\section{Table of Contents}

Expanded methods3

Overview3

Data analysis4

Feature importance analysis4

Data processing4

Data modelling4

Forecasting modelling5

Algorithm application6

Supplementary figure 1. Flowchart of data cleaning and inclusion criteria7

Supplementary Table 1. Mean difference between observed and predicted salt intake by sex across all ML algorithms8

Supplementary Table 2. Weighted distribution of predictors in each survey included in the ML model development.10

Supplementary Table 3. Observed and predicted mean salt intake (g/day) by sex in each survey included in the ML model development.14

Supplementary Table 4. Mean difference between observed and predicted salt intake by sex in each survey included in the ML model development.17

Supplementary Table 5. Observed mean salt intake ( $\mathrm{g} / \mathrm{day}$ ) by equation and sex in each survey included in the ML model development.20

Supplementary Table 6. Weighted distribution of predictors in each of the 49 national surveys included in the application of the model herein developed.25

Supplementary Table 7. Predicted mean salt intake ( $g /$ day) by sex in each of the 49 national surveys included in the application of the model herein developed.29

Supplementary Table 8. Comparison between mean salt intake predictions and global estimates across national surveys included in the ML application.34 
medRxiv preprint doi: https://doi.org/10.1101/2021.08.31.21262944; this version posted September 2, 2021. The copyright holder for this preprint (which was not certified by peer review) is the author/funder, who has granted medRxiv a license to display the preprint in perpetuity.

It is made available under a CC-BY 4.0 International license .

\section{Expanded methods}

\section{Overview}

We worked with a structured dataset which mostly had numeric attributes (variables). Given our study problem, we opted for a supervised learning model because there was a target attribute (i.e., salt consumption at the subject level); specifically, we conducted a supervised regression because the target attribute was a numeric variable. For the machine learning analyses we used Python and the Scikit-Learn library.

First, we developed a pipeline for data management and model development. This way, we followed a consistent and transparent methodology to secure an optimal model for the training set and that would adequately generalize to other (unseen) datasets. The following figure depicts the pipeline we developed: i) we studied the available data and where needed, we did a one-hot encoding; ii) we did feature importance analysis; iii) we chose and tried different scaling and transformation methods, so that all variables would be in the same scale or units; iv) we tried a set of machine learning models, including a customized neural network; v) we forecasted (predicted) the attribute of interest (salt consumption at the subject level) in an unseen dataset (i.e., not used for model training). Notably, we went backwards and forwards (see arrows in the figure) between the four first stages until we reached the best combinations and results for each model. In the following sections, we will describe each of these five stages.

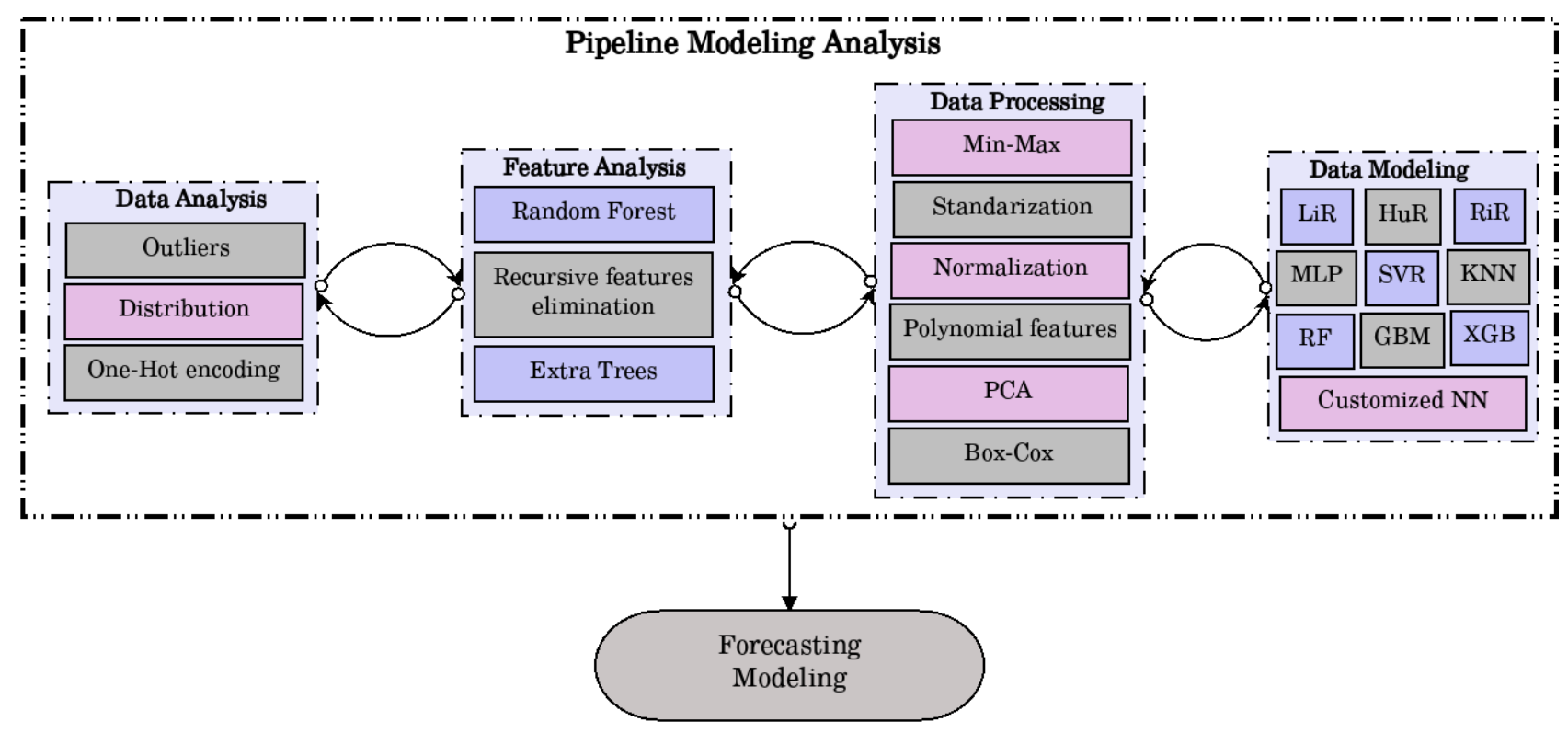


medRxiv preprint doi: https://doi.org/10.1101/2021.08.31.21262944; this version posted September 2,2021 . The copyright holder for this preprint (which was not certified by peer review) is the author/funder, who has granted medRxiv a license to display the preprint in It is made available under a CC-BY 4.0 International license.

\section{Data analysis}

This was an exploratory analysis to understand the dataset and its characteristics. We worked with a complete-case dataset; in other words, we excluded missing observations in the variables considered in the analysis. Consequently, we did not do any data imputation analysis.

We explored the distribution of all numerical variables, which were in different units and scales; this exploratory analysis informed the choices of data processing methods (e.g., Box-Cox) implemented in the third stage.

\section{Feature importance analysis}

Even though we followed expert knowledge to select a reduced, though relevant number of predictors to be included in the regression model, we conducted feature importance analyses to understand the role each predictor would play in the model. This process aimed to eliminate variables that would not carry substantial information for the model. We used Random Forest, Recursive Feature Elimination and Extra Trees. Consistently, these three methods suggested that all the chosen predictors would contribute to a better model.

\section{Data processing}

As described in the data analysis section (first stage), numeric variables were in different units and scales; therefore, these variables needed to be scaled or transformed. This scaling would also help to find a better prediction model. It is common knowledge that machine learning models would perform differently (and better) depending on data transformation methods. We did: i) Min-Max whereby numeric variables were scaled to a range between 0 and 1; ii) Standardization; iii) Normalization: iv) Polynomial features of degree 2 (quadratic polynomial); v) Principal Component Analysis with 3 components and explained variance of $\geq 0.95$; and vi) Box-Cox.

\section{Data modelling}

There are several machine learning algorithms for a supervised regression model. Those that we used, and that are depicted in the figure, yielded much better results and were studied in detail. That is, at the beginning of our work we explored other algorithms, though these did not perform well and were not considered thereafter. The algorithms we considered were: i) Linear Regression (LiR); ii) Hubber Regressor (HuR); iii) Ridge Regressor (RiR); iv) Multilayer Perceptron (MLP); v) Support Vector Regressor (SVR); vi) k-Nearest Neighbors (KNN); vii) Random Forest (RF); viii) Gradient Boost Machine (GBM); and ix) Extreme Gradient Boosting (XBG). 
medRxiv preprint doi: https://doi.org/10.1101/2021.08.31.21262944; this version posted September 2, 2021. The copyright holder for this preprint (which was not certified by peer review) is the author/funder, who has granted medRxiv a license to display the preprint in perpetuity.

It is made available under a CC-BY 4.0 International license .

In addition to these nine machine learning algorithms, we also implemented a neural network (see figure below). This neural network was optimized empirically. We used a batch size $=256$; epochs $=300$; and optimizer = 'adam'. The neural network was implemented in Python using the Keras library.

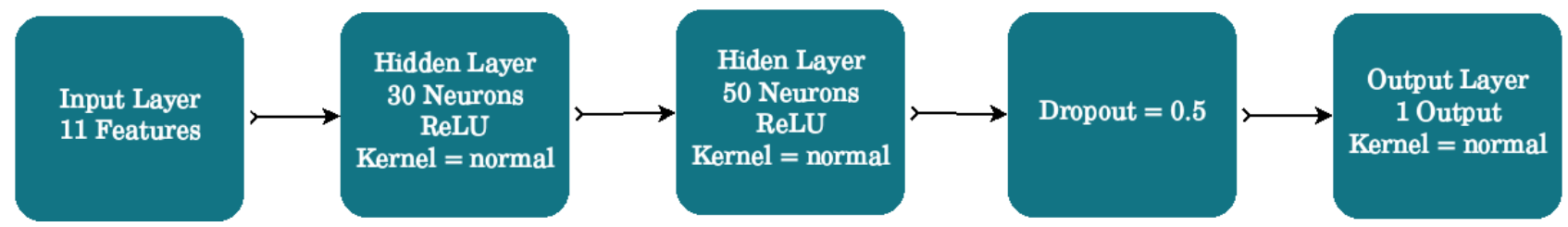

For each model and processing method (see Data Processing section) we studied the $\mathrm{R}^{2}$, Mean Absolute Error (MAE) and Root Mean Square Error (RMSE). As shown in the table, all algorithms showed a similar performance. Because all the algorithms had an equivalent performance, the chosen one needed to be defined at the forecasting stage; that is, the one that would generalize better to new (unseen) data.

\begin{tabular}{lllll}
\hline \multicolumn{1}{c}{ Algorithm } & Processing & $\mathbf{R}^{\mathbf{2}}$ & MAE & RMSE \\
\hline LiR & Polynomial $(\mathrm{g}=2)$ & 0.442 & 1.1156 & 1.4456 \\
\hline HuB & Polynomial(g=2) & 0.442 & 1.1156 & 1.4455 \\
\hline RiR & Polynomial(g=2) & 0.441 & 1.1163 & 1.4135 \\
\hline MLP & BoxCox & 0.445 & 1.1096 & 1.4418 \\
\hline SVR & MinMax & 0.440 & 1.1000 & 1.4480 \\
\hline KNN & Standarized & 0.416 & 1.1437 & 1.4478 \\
\hline RF & Polynomial(g=2) & 0.422 & 1.1373 & 1.4717 \\
\hline GBM & MinMax & 0.443 & 1.1146 & 1.4432 \\
\hline XGB & BoxCox & 0.424 & 1.1134 & 1.4687 \\
\hline Customized NN & BoxCox & 0.456 & 1.1045 & 1.4445 \\
\hline
\end{tabular}

\section{Forecasting modelling}

This stage implies studying the predicted results in new (unseen) data (i.e., data not used for model training). For this stage we used the validation and test datasets. We chose the model that yielded predictions closest to the observed results. In this line, we compared the mean difference between the observed and predicted mean salt intake results (i.e., observed - predicted) across all prediction algorithms.

We observed there was no unique algorithm that had the mean difference closest to zero in men and women at the same time (Supplementary table 1). The RF algorithm had the mean difference closest to zero in both sexes combined (mean difference $=0.0004$ ), the MLP algorithm performed the best in 
medRxiv preprint doi: https://doi.org/10.1101/2021.08.31.21262944; this version posted September 2,2021 . The copyright holder for this preprint (which was not certified by peer review) is the author/funder, who has granted medRxiv a license to display the preprint in It is made available under a CC-BY 4.0 International license.

men (mean difference $=0.0052$ ), and in women the GBR algorithm showed the best results (mean difference $=-0.0005)$.

To support our decision process, we plotted the mean differences in men and women for each survey (Supplementary figure 2); this figure only included the predictions based on the top five algorithms (RF, MLP, GBR, LiR and RiR). We counted how many times (i.e., number of surveys) each algorithm had the mean difference closest to zero.

Because the RF algorithm had the mean difference closest to zero in both sexes combined and it was among the top 5 algorithms in men and women (Supplementary table 1), we decided to choose the RF algorithm. Additionally, predictions based on the RF algorithm were the closest to zero across surveys (Supplementary figure 2). These analyses were performed in R (version 4.0.3).

\section{Algorithm application}

To make the predictions in the new 49 datasets without information about urine samples, we used the RF model (i.e., ML algorithm and predictors) developed following the methods above described (see Forecasting Modelling section). We re-trained the model with the full dataset used for model development and validation (i.e., train, validated and test dataset pooled), and then predicted the outcome (i.e., mean salt intake) in the 49 new datasets. 
medRxiv preprint doi: https://doi.org/10.1101/2021.08.31.21262944; this version posted September 2, 2021. The copyright holder for this preprint (which was not certified by peer review) is the author/funder, who has granted medRxiv a license to display the preprint in It is made available under a CC-BY 4.0 International license.

\section{Supplementary figure 1. Flowchart of data cleaning and inclusion criteria}

\section{Sample $=97,229$ observations}

Sample $=96,738$ observations [age between 15-69 years]

Sample $=53,821$ observations [complete-case in height, weight, blood pressure, urine creatinine and sodium]

Sample $=53,795$ observations

[plausible values in height, weight, blood pressure and BMI]

Sample $=53,790$ observations [non- pregnant women]

Sample $=51,553$ observations [excluded Georgia, Afghanistan and Tonga because inconsistent urine creatinine or missing data]

Sample $=46,220$ observations [plausible urine creatinine values]

Sample $=46,215$ observations [only positive values on estimated salt intake]

Sample $=45,152$ observations [estimated salt intake values within 3 standard deviations from their mean]

Total sample $=45,152$ observations [46.4\% of initial sample size] 
medRxiv preprint doi: https://doi.org/10.1101/2021.08.31.21262944; this version posted September 2, 2021. The copyright holder for this preprint (which was not certified by peer review) is the author/funder, who has granted medRxiv a license to display the preprint in perpetuity.

It is made available under a CC-BY 4.0 International license .

Supplementary Table 1. Mean difference between observed and predicted salt intake by sex across all ML algorithms

\begin{tabular}{|c|c|c|}
\hline ML algorithm & $\begin{array}{l}\text { Mean difference between observed } \\
\text { and predicted mean salt intake }\end{array}$ & Sex \\
\hline prediction_CNN_boxcox & 0.0308 & both sexes \\
\hline prediction_CNN_standardized & 0.023 & both sexes \\
\hline prediction_GBR_boxcox & 0.1781 & both sexes \\
\hline prediction_GBR_minmax & 0.1739 & both sexes \\
\hline prediction_GBR_orig & 0.0221 & both sexes \\
\hline prediction_GBR_standarized & 0.1809 & both sexes \\
\hline prediction_HBR_poly & 0.1372 & both sexes \\
\hline prediction_HGB_boxcox & 0.0935 & both sexes \\
\hline prediction_HGB_orig & 0.0676 & both sexes \\
\hline prediction_HGB_standardized & 0.0681 & both sexes \\
\hline prediction_KNN_boxcox & 0.0443 & both sexes \\
\hline prediction_KNN_standarized & 0.0289 & both sexes \\
\hline prediction_LiR_poly & 0.0187 & both sexes \\
\hline prediction_MLP_boxcox & -0.0238 & both sexes \\
\hline prediction_MLP_minmax & -0.1559 & both sexes \\
\hline prediction_MLP_standarized & -0.0659 & both sexes \\
\hline prediction_RF_poly & 0.0004 & both sexes \\
\hline prediction_RiR_poly & 0.0172 & both sexes \\
\hline prediction_SVR_minmax & 0.1675 & both sexes \\
\hline prediction_XGB_boxcox & 0.0935 & both sexes \\
\hline prediction_XGB_minmax & -1.161 & both sexes \\
\hline prediction_XGB_orig & 0.0295 & both sexes \\
\hline prediction_XGB_standardized & 0.0249 & both sexes \\
\hline prediction_CNN_boxcox & 0.0546 & men \\
\hline prediction_CNN_standardized & 0.0514 & men \\
\hline prediction_GBR_boxcox & 0.1788 & men \\
\hline prediction_GBR_minmax & 0.1728 & men \\
\hline prediction_GBR_orig & 0.0447 & men \\
\hline prediction_GBR_standarized & 0.1859 & men \\
\hline prediction_HBR_poly & 0.1621 & men \\
\hline prediction_HGB_boxcox & 0.0605 & men \\
\hline prediction_HGB_orig & 0.0237 & men \\
\hline
\end{tabular}




\begin{tabular}{|c|c|c|}
\hline prediction_HGB_standardized & 0.0285 & men \\
\hline prediction_KNN_boxcox & 0.0724 & men \\
\hline prediction_KNN_standarized & 0.053 & men \\
\hline prediction_LiR_poly & 0.0384 & men \\
\hline prediction_MLP_boxcox & 0.0052 & men \\
\hline prediction_MLP_minmax & -0.1718 & men \\
\hline prediction_MLP_standarized & -0.0859 & men \\
\hline prediction_RF_poly & 0.0199 & men \\
\hline prediction_RiR_poly & 0.0369 & men \\
\hline prediction_SVR_minmax & 0.1541 & men \\
\hline prediction_XGB_boxcox & 0.0605 & men \\
\hline prediction_XGB_minmax & -0.2716 & men \\
\hline prediction_XGB_orig & 0.0488 & men \\
\hline prediction_XGB_standardized & 0.0481 & men \\
\hline prediction_CNN_boxcox & 0.0071 & women \\
\hline prediction_CNN_standardized & -0.0053 & women \\
\hline prediction_GBR_boxcox & 0.1774 & women \\
\hline prediction_GBR_minmax & 0.175 & women \\
\hline prediction_GBR_orig & -0.0005 & women \\
\hline prediction_GBR_standarized & 0.1759 & women \\
\hline prediction_HBR_poly & 0.1122 & women \\
\hline prediction_HGB_boxcox & 0.1266 & women \\
\hline prediction_HGB_orig & 0.1114 & women \\
\hline prediction_HGB_standardized & 0.1077 & women \\
\hline prediction_KNN_boxcox & 0.0161 & women \\
\hline prediction_KNN_standarized & 0.0047 & women \\
\hline prediction_LiR_poly & -0.0009 & women \\
\hline prediction_MLP_boxcox & -0.0529 & women \\
\hline prediction_MLP_minmax & -0.1401 & women \\
\hline prediction_MLP_standarized & -0.0458 & women \\
\hline prediction_RF_poly & -0.0192 & women \\
\hline prediction_RiR_poly & -0.0025 & women \\
\hline prediction_SVR_minmax & 0.181 & women \\
\hline prediction_XGB_boxcox & 0.1266 & women \\
\hline prediction_XGB_minmax & -2.0504 & women \\
\hline prediction_XGB_orig & 0.0102 & women \\
\hline prediction_XGB_standardized & 0.0018 & women \\
\hline
\end{tabular}


Supplementary Table 2. Weighted distribution of predictors in each survey included in the ML model development.

\begin{tabular}{|c|c|c|c|c|c|c|c|c|c|c|c|c|}
\hline Country & Year & Region & $\begin{array}{l}\text { Sample } \\
\text { size (n) }\end{array}$ & $\begin{array}{l}\text { Mean } \\
\text { age } \\
\text { (years) }\end{array}$ & $\begin{array}{l}\text { Age } \\
\text { range } \\
\text { (years) }\end{array}$ & $\begin{array}{l}\text { Proportion } \\
\text { of men }(\%)\end{array}$ & $\begin{array}{l}\text { Mean, } \\
\text { minimum } \\
\text { and } \\
\text { maximum } \\
\text { values of } \\
\text { SBP } \\
(\mathrm{mmHg})\end{array}$ & \begin{tabular}{|l} 
Mean, \\
minimum \\
and \\
maximum \\
values of \\
DBP \\
$(\mathrm{mmHg})$
\end{tabular} & $\begin{array}{l}\text { Mean, } \\
\text { minimum } \\
\text { and } \\
\text { maximum } \\
\text { values of } \\
\text { weight } \\
(\mathrm{kg})\end{array}$ & $\begin{array}{l}\text { Mean, } \\
\text { minimum } \\
\text { and } \\
\text { maximum } \\
\text { values of } \\
\text { height }(\mathrm{m})\end{array}$ & $\begin{array}{l}\text { Mean, } \\
\text { minimum } \\
\text { and } \\
\text { maximum } \\
\text { values of } \\
\text { urinary } \\
\text { sodium } \\
\text { (mmol/L) }\end{array}$ & $\begin{array}{l}\text { Mean, } \\
\text { minimum } \\
\text { and } \\
\text { maximum } \\
\text { values of } \\
\text { urinary } \\
\text { creatinine } \\
\text { (mmol/L) }\end{array}$ \\
\hline Armenia & 2016 & Europe & 1074 & 40 & $18-69$ & 49.7 & $\begin{array}{l}129.5(86- \\
237.5)\end{array}$ & $\begin{array}{l}84.5(49- \\
147.5)\end{array}$ & $\begin{array}{l}70.9 \\
139)\end{array}$ & $\begin{array}{l}1.66(1.27- \\
1.89)\end{array}$ & $\begin{array}{l}128.6 \\
(10.6- \\
237.6)\end{array}$ & $\begin{array}{l}10.1(1.9- \\
27.3)\end{array}$ \\
\hline Azerbaijan & 2017 & Europe & 2359 & 39 & $18-69$ & 49.5 & $\begin{array}{l}125.9 \\
(81.5-230)\end{array}$ & $\begin{array}{l}81.4(47.5- \\
142.5)\end{array}$ & $\begin{array}{l}73.1(36- \\
174)\end{array}$ & $\begin{array}{l}1.67(1.15- \\
1.98)\end{array}$ & $\begin{array}{l}167.7(2- \\
389)\end{array}$ & $\begin{array}{l}11.9(1.8- \\
31.8)\end{array}$ \\
\hline Bangladesh & 2018 & $\begin{array}{l}\text { Southeast } \\
\text { Asia }\end{array}$ & 5815 & 39 & $18-69$ & 47.4 & $\begin{array}{l}120.2(72- \\
251)\end{array}$ & $\begin{array}{l}78.6(32- \\
147)\end{array}$ & $\begin{array}{l}55.6(28- \\
111)\end{array}$ & $\begin{array}{l}1.56(1- \\
2.11)\end{array}$ & $\begin{array}{l}119.9(4- \\
403)\end{array}$ & $\begin{array}{l}8.4(2.2- \\
32.3)\end{array}$ \\
\hline Belarus & 2017 & Europe & 4506 & 43 & $18-69$ & 47.1 & $\begin{array}{l}134.6 \\
(87.5-257)\end{array}$ & $\begin{array}{l}84.9(53.5- \\
147)\end{array}$ & $\begin{array}{l}77.7(41- \\
144)\end{array}$ & $\begin{array}{l}1.7(1.05- \\
1.99)\end{array}$ & $\begin{array}{l}149.6 \\
(10.5- \\
371.4)\end{array}$ & $\begin{array}{l}12.2(1.8- \\
32.7)\end{array}$ \\
\hline
\end{tabular}




\begin{tabular}{|c|c|c|c|c|c|c|c|c|c|c|c|c|}
\hline Bhutan & 2014 & $\begin{array}{l}\text { Southeast } \\
\text { Asia }\end{array}$ & 5734 & 38 & |18-69 & 59.1 & \begin{tabular}{|l}
$125.6(75-$ \\
$228.5)$
\end{tabular} & \begin{tabular}{|l}
$84.5(46-$ \\
$141.5)$
\end{tabular} & \begin{tabular}{|l}
$61.4(23-$ \\
$115)$
\end{tabular} & \begin{tabular}{|l}
$1.6(1.11-$ \\
$1.96)$
\end{tabular} & \begin{tabular}{|l}
$142.2(6-$ \\
$388)$
\end{tabular} & \begin{tabular}{|l}
$8.1(1.9-$ \\
$29.7)$
\end{tabular} \\
\hline Bhutan & 2019 & $\begin{array}{l}\text { Southeast } \\
\text { Asia }\end{array}$ & 5734 & 34 & $15-69$ & 56.5 & $\begin{array}{l}122.9(85- \\
224.5)\end{array}$ & $\begin{array}{l}80.7 \text { (43.5- } \\
137)\end{array}$ & \begin{tabular}{|l|}
$61.4(28.5-$ \\
$140)$
\end{tabular} & $\begin{array}{l}1.58(1.07- \\
1.92)\end{array}$ & $\begin{array}{l}130.5 \text { (4.7- } \\
444.9)\end{array}$ & $\begin{array}{l}10.4(1.8- \\
32.7)\end{array}$ \\
\hline $\begin{array}{l}\text { Brunei } \\
\text { Darussalam }\end{array}$ & 2016 & $\begin{array}{l}\text { Western } \\
\text { Pacific }\end{array}$ & 1636 & 35 & $18-69$ & 51.5 & \begin{tabular}{|l}
122.6 \\
$(75.5-218)$
\end{tabular} & $\begin{array}{l}78.4 \text { (45.5- } \\
138)\end{array}$ & $\begin{array}{l}69(31.2- \\
138.3)\end{array}$ & $\begin{array}{l}1.59(1.32- \\
1.84)\end{array}$ & \begin{tabular}{|l}
122.6 \\
$(19.9-329)$
\end{tabular} & $\begin{array}{l}12.6(1.8- \\
32.6)\end{array}$ \\
\hline Jordan & 2019 & \begin{tabular}{|l|} 
Eastern \\
Mediterranean
\end{tabular} & 1040 & 37 & $18-69$ & 50.2 & $\begin{array}{l}117.7(75- \\
200)\end{array}$ & \begin{tabular}{|l}
$78.4(50-$ \\
$119.5)$
\end{tabular} & \begin{tabular}{|l}
$76.3(35.5-$ \\
$159.5)$
\end{tabular} & $\begin{array}{l}1.66(1.36- \\
1.95)\end{array}$ & $\begin{array}{l}165.4(13- \\
365)\end{array}$ & \begin{tabular}{|l}
$13.6(1.8-$ \\
$32.5)$
\end{tabular} \\
\hline Lebanon & 2017 & \begin{tabular}{|l|} 
Eastern \\
Mediterranean
\end{tabular} & 999 & 42 & $17-69$ & 48.7 & $\begin{array}{l}128.5(80- \\
214.5)\end{array}$ & \begin{tabular}{|l}
$76.9(35-$ \\
$123)$
\end{tabular} & $\begin{array}{l}78.3(40- \\
141)\end{array}$ & $\begin{array}{l}1.68(1.2- \\
1.96)\end{array}$ & \begin{tabular}{|l}
$124.4(4-$ \\
$385)$
\end{tabular} & $\begin{array}{l}11.5(1.9- \\
32)\end{array}$ \\
\hline Malawi & 2017 & Africa & 1603 & 35 & $18-69$ & 56.3 & \begin{tabular}{|l|}
121.8 \\
$(74.5-$ \\
$221.5)$
\end{tabular} & $\begin{array}{l}75.6(39.5- \\
142.5)\end{array}$ & $\begin{array}{l}58.4 \text { (33.6- } \\
119)\end{array}$ & $\begin{array}{l}1.61(1.36- \\
1.96)\end{array}$ & $\begin{array}{l}186.5(11- \\
399.9)\end{array}$ & \begin{tabular}{|l}
$10.7(1.9-$ \\
$32.4)$
\end{tabular} \\
\hline Mongolia & 2013 & $\begin{array}{l}\text { Western } \\
\text { Pacific }\end{array}$ & 7508 & 42 & $15-64$ & 50.3 & $\begin{array}{l}129.3 \\
(88.5- \\
219.5)\end{array}$ & $\begin{array}{l}82.1(49.5- \\
133.5)\end{array}$ & $\begin{array}{l}71 \text { (30.6- } \\
138)\end{array}$ & $\begin{array}{l}1.62(1.27- \\
1.92)\end{array}$ & $\begin{array}{l}134.1 \\
(13.1-515)\end{array}$ & $\begin{array}{l}10.9(1.8- \\
31.9)\end{array}$ \\
\hline
\end{tabular}




\begin{tabular}{|c|c|c|c|c|c|c|c|c|c|c|c|c|}
\hline Mongolia & 2019 & $\begin{array}{l}\text { Western } \\
\text { Pacific }\end{array}$ & 7508 & 36 & $15-69$ & 50.9 & $\begin{array}{l}120.4 \\
(76.5- \\
253.5)\end{array}$ & $\begin{array}{l}77.2(48- \\
143)\end{array}$ & $\begin{array}{l}68.5(29- \\
159)\end{array}$ & \begin{tabular}{|l|}
$1.64(1.34-$ \\
$1.98)$
\end{tabular} & $\begin{array}{l}117.1(2.1- \\
348.9)\end{array}$ & $\begin{array}{l}7.5(1.8- \\
28.3)\end{array}$ \\
\hline Morocco & 2017 & $\begin{array}{l}\text { Eastern } \\
\text { Mediterranean }\end{array}$ & 3438 & 40 & $18-69$ & 50.6 & $\begin{array}{l}128.1(83- \\
228.5)\end{array}$ & $\begin{array}{l}78.1(40- \\
139)\end{array}$ & $\begin{array}{l}70.9 \\
168)\end{array}$ & $\begin{array}{l}1.66(1.34- \\
1.95)\end{array}$ & $\begin{array}{l}122.3 \\
(26.3- \\
575.2)\end{array}$ & $\begin{array}{l}10.3(1.8- \\
31.4)\end{array}$ \\
\hline Nepal & 2019 & $\begin{array}{l}\text { Southeast } \\
\text { Asia }\end{array}$ & 2442 & 36 & $15-69$ & 40.7 & $\begin{array}{l}122.8(81- \\
212.5)\end{array}$ & $\begin{array}{l}80.5(55- \\
146.5)\end{array}$ & $\begin{array}{l}54.4(26- \\
160)\end{array}$ & $\begin{array}{l}1.55(1.21- \\
2.03)\end{array}$ & $\begin{array}{l}142.3(3- \\
437)\end{array}$ & $\begin{array}{l}5.6(1.8- \\
25.5)\end{array}$ \\
\hline $\begin{array}{l}\text { Solomon } \\
\text { Islands }\end{array}$ & 2015 & $\begin{array}{l}\text { Western } \\
\text { Pacific }\end{array}$ & 172 & 38 & $18-69$ & 61.4 & $\begin{array}{l}121(88.5- \\
188.5)\end{array}$ & $\begin{array}{l}76.5(52- \\
104.5)\end{array}$ & $\begin{array}{l}67.9 \text { (38.5- } \\
122)\end{array}$ & $\begin{array}{l}1.61(1.41- \\
1.8)\end{array}$ & $\begin{array}{l}99.3(7- \\
250)\end{array}$ & $\begin{array}{l}9.7(1.9- \\
28.4)\end{array}$ \\
\hline Sudan & 2016 & $\begin{array}{l}\text { Eastern } \\
\text { Mediterranean }\end{array}$ & 571 & 36 & $18-69$ & 55.9 & $\begin{array}{l}128.2(89- \\
231)\end{array}$ & $\begin{array}{l}84.9(58- \\
131.5)\end{array}$ & $\begin{array}{l}72.2 \text { (35.6- } \\
174)\end{array}$ & $\begin{array}{l}1.67(1.42- \\
1.92)\end{array}$ & $\begin{array}{l}128.5(5- \\
459)\end{array}$ & $\begin{array}{l}14(1.9- \\
32.4)\end{array}$ \\
\hline Tokelau & 2014 & $\begin{array}{l}\text { Western } \\
\text { Pacific }\end{array}$ & 182 & 35 & $18-63$ & 56.2 & $\begin{array}{l}124.8(76- \\
184.5)\end{array}$ & $\begin{array}{l}79(53- \\
128.5)\end{array}$ & $\begin{array}{l}94.7(58- \\
158.3)\end{array}$ & $\begin{array}{l}1.71(1.16- \\
1.88)\end{array}$ & $\begin{array}{l}62.9(20- \\
265)\end{array}$ & $5(2-7.7)$ \\
\hline Turkmenistan & 2018 & Europe & 3584 & 37 & $18-69$ & 52.7 & $\begin{array}{l}127.5 \\
(87.5-268)\end{array}$ & $\begin{array}{l}82.9(54.5- \\
149)\end{array}$ & $\begin{array}{l}72.4(39- \\
142)\end{array}$ & $\begin{array}{l}1.68(1.16- \\
1.98)\end{array}$ & $\begin{array}{l}109.2(10- \\
163)\end{array}$ & $\begin{array}{l}11.1(4.5- \\
18.3)\end{array}$ \\
\hline
\end{tabular}




\begin{tabular}{|l|l|l|l|l|l|l|l|l|l|l|l|}
\hline Zambia & 2017 & Africa & 2489 & 33 & $18-69$ & 50.3 & $\begin{array}{l}124.8(73- \\
248)\end{array}$ & $\begin{array}{l}77(35.5- \\
147.5)\end{array}$ & $\begin{array}{l}60.9(33.8- \\
150)\end{array}$ & $\begin{array}{l}1.62(1.01- \\
2.07)\end{array}$ & $\begin{array}{l}137.1(10- \\
375)\end{array}$ \\
\hline
\end{tabular}


medRxiv preprint doi: https://doi.org/10.1101/2021.08.31.21262944; this version posted September 2, 2021. The copyright holder for this preprint (which was not certified by peer review) is the author/funder, who has granted medRxiv a license to display the preprint in It is made available under a CC-BY 4.0 International license.

Supplementary Table 3. Observed and predicted mean salt intake (g/day) by sex in each survey included in the ML model development.

\begin{tabular}{|c|c|c|c|c|c|c|}
\hline Country & Year & Sex & $\begin{array}{l}\text { Mean salt } \\
\text { intake (g/day) }\end{array}$ & \begin{tabular}{|l|} 
Mean salt intake \\
(g/day) lower
\end{tabular} & $\begin{array}{l}\text { Mean salt intake } \\
\text { (g/day) upper }\end{array}$ & Category \\
\hline Armenia & 2016 & Men & 9.41 & 9.13 & 9.7 & $\begin{array}{l}\mathrm{ML} \\
\text { predicted }\end{array}$ \\
\hline Armenia & 2016 & Men & 9.44 & 9.05 & 9.83 & Observed \\
\hline Armenia & 2016 & Women & 7.54 & 7.38 & 7.71 & $\begin{array}{l}\text { ML } \\
\text { predicted }\end{array}$ \\
\hline Armenia & 2016 & Women & 7.47 & 7.28 & 7.66 & Observed \\
\hline Azerbaijan & 2017 & Men & 9.51 & 9.37 & 9.65 & $\begin{array}{l}\mathrm{ML} \\
\text { predicted }\end{array}$ \\
\hline Azerbaijan & 2017 & Men & 10.28 & 9.99 & 10.58 & Observed \\
\hline Azerbaijan & 2017 & Women & 7.57 & 7.45 & 7.69 & $\begin{array}{l}\text { ML } \\
\text { predicted }\end{array}$ \\
\hline Azerbaijan & 2017 & Women & 8.01 & 7.77 & 8.25 & Observed \\
\hline Bangladesh & 2018 & Men & 8.68 & 8.59 & 8.77 & $\begin{array}{l}\mathrm{ML} \\
\text { predicted }\end{array}$ \\
\hline Bangladesh & 2018 & Men & 8.56 & 8.4 & 8.72 & Observed \\
\hline Bangladesh & 2018 & Women & 7.41 & 7.34 & 7.48 & $\begin{array}{l}\mathrm{ML} \\
\text { predicted }\end{array}$ \\
\hline Bangladesh & 2018 & Women & 7.24 & 7.12 & 7.35 & Observed \\
\hline Belarus & 2017 & Men & 9.73 & 9.62 & 9.85 & $\begin{array}{l}\mathrm{ML} \\
\text { predicted }\end{array}$ \\
\hline Belarus & 2017 & Men & 9.92 & 9.69 & 10.14 & Observed \\
\hline Belarus & 2017 & Women & 7.45 & 7.36 & 7.53 & $\begin{array}{l}\mathrm{ML} \\
\text { predicted }\end{array}$ \\
\hline Belarus & 2017 & Women & 7.56 & 7.41 & 7.71 & Observed \\
\hline Bhutan & 2014 & Men & 9.04 & 8.88 & 9.19 & $\begin{array}{l}\text { ML } \\
\text { predicted }\end{array}$ \\
\hline Bhutan & 2014 & Men & 9.49 & 9.12 & 9.86 & Observed \\
\hline Bhutan & 2014 & Women & 7.55 & 7.46 & 7.65 & $\begin{array}{l}\mathrm{ML} \\
\text { predicted }\end{array}$ \\
\hline Bhutan & 2014 & Women & 8.11 & 7.88 & 8.34 & Observed \\
\hline Bhutan & 2019 & Men & 9.14 & 8.99 & 9.29 & $\begin{array}{l}\mathrm{ML} \\
\text { predicted }\end{array}$ \\
\hline Bhutan & 2019 & Men & 8.83 & 8.6 & 9.06 & Observed \\
\hline Bhutan & 2019 & Women & 7.51 & 7.42 & 7.59 & $\begin{array}{l}\mathrm{ML} \\
\text { predicted }\end{array}$ \\
\hline Bhutan & 2019 & Women & 7.42 & 7.24 & 7.59 & Observed \\
\hline \begin{tabular}{|l} 
Brunei \\
Darussalam
\end{tabular} & 2016 & Men & 9.92 & 9.72 & 10.11 & $\begin{array}{l}\mathrm{ML} \\
\text { predicted }\end{array}$ \\
\hline
\end{tabular}


medRxiv preprint doi: https://doi.org/10.1101/2021.08.31.21262944; this version posted September 2, 2021. The copyright holder for this preprint (which was not certified by peer review) is the author/funder, who has granted medRxiv a license to display the preprint in It is made available under a CC-BY 4.0 International license.

\begin{tabular}{|c|c|c|c|c|c|c|}
\hline \begin{tabular}{|l} 
Brunei \\
Darussalam
\end{tabular} & 2016 & Men & 9.37 & 9.07 & 9.67 & Observed \\
\hline $\begin{array}{l}\text { Brunei } \\
\text { Darussalam }\end{array}$ & 2016 & Women & 7.8 & 7.66 & 7.95 & $\begin{array}{l}\mathrm{ML} \\
\text { predicted }\end{array}$ \\
\hline $\begin{array}{l}\text { Brunei } \\
\text { Darussalam }\end{array}$ & 2016 & Women & 7.1 & 6.87 & 7.32 & Observed \\
\hline Jordan & 2019 & Men & 9.6 & 9.17 & 10.02 & $\begin{array}{l}\mathrm{ML} \\
\text { predicted }\end{array}$ \\
\hline Jordan & 2019 & Men & 10.26 & 9.65 & 10.87 & Observed \\
\hline Jordan & 2019 & Women & 8 & 7.71 & 8.29 & $\begin{array}{l}\mathrm{ML} \\
\text { predicted }\end{array}$ \\
\hline Jordan & 2019 & Women & 8.4 & 8.03 & 8.77 & Observed \\
\hline Lebanon & 2017 & Men & 10.08 & 9.67 & 10.48 & $\begin{array}{l}\mathrm{ML} \\
\text { predicted }\end{array}$ \\
\hline Lebanon & 2017 & Men & 9.33 & 8.88 & 9.78 & Observed \\
\hline Lebanon & 2017 & Women & 7.63 & 7.46 & 7.81 & $\begin{array}{l}\mathrm{ML} \\
\text { predicted }\end{array}$ \\
\hline Lebanon & 2017 & Women & 7.53 & 6.93 & 8.13 & Observed \\
\hline Malawi & 2017 & Men & 8.7 & 8.57 & 8.82 & $\begin{array}{l}\mathrm{ML} \\
\text { predicted }\end{array}$ \\
\hline Malawi & 2017 & Men & 10.09 & 9.61 & 10.57 & Observed \\
\hline Malawi & 2017 & Women & 7.38 & 7.24 & 7.52 & $\begin{array}{l}\text { ML } \\
\text { predicted }\end{array}$ \\
\hline Malawi & 2017 & Women & 8.4 & 8.07 & 8.74 & Observed \\
\hline Mongolia & 2013 & Men & 9.64 & 9.46 & 9.82 & $\begin{array}{l}\mathrm{ML} \\
\text { predicted }\end{array}$ \\
\hline Mongolia & 2013 & Men & 9.71 & 9.31 & 10.1 & Observed \\
\hline Mongolia & 2013 & Women & 7.84 & 7.74 & 7.94 & $\begin{array}{l}\mathrm{ML} \\
\text { predicted }\end{array}$ \\
\hline Mongolia & 2013 & Women & 7.72 & 7.52 & 7.92 & Observed \\
\hline Mongolia & 2019 & Men & 9.41 & 9.31 & 9.51 & $\begin{array}{l}\mathrm{ML} \\
\text { predicted }\end{array}$ \\
\hline Mongolia & 2019 & Men & 9.71 & 9.55 & 9.86 & Observed \\
\hline Mongolia & 2019 & Women & 7.55 & 7.48 & 7.62 & $\begin{array}{l}\text { ML } \\
\text { predicted }\end{array}$ \\
\hline Mongolia & 2019 & Women & 7.43 & 7.31 & 7.56 & Observed \\
\hline Morocco & 2017 & Men & 9.25 & 9.12 & 9.39 & $\begin{array}{l}\mathrm{ML} \\
\text { predicted }\end{array}$ \\
\hline Morocco & 2017 & Men & 9.04 & 8.82 & 9.26 & Observed \\
\hline Morocco & 2017 & Women & 7.65 & 7.58 & 7.72 & $\begin{array}{l}\mathrm{ML} \\
\text { predicted }\end{array}$ \\
\hline Morocco & 2017 & Women & 7.5 & 7.39 & 7.62 & Observed \\
\hline Nepal & 2019 & Men & 8.81 & 8.5 & 9.13 & $\begin{array}{l}\text { ML } \\
\text { predicted }\end{array}$ \\
\hline
\end{tabular}


medRxiv preprint doi: https://doi.org/10.1101/2021.08.31.21262944; this version posted September 2, 2021. The copyright holder for this preprint (which was not certified by peer review) is the author/funder, who has granted medRxiv a license to display the preprint in It is made available under a CC-BY 4.0 International license.

\begin{tabular}{|c|c|c|c|c|c|c|}
\hline Nepal & 2019 & Men & 9.63 & 9.25 & 10 & Observed \\
\hline Nepal & 2019 & Women & 7.27 & 7.17 & 7.37 & $\begin{array}{l}\text { ML } \\
\text { predicted }\end{array}$ \\
\hline Nepal & 2019 & Women & 7.98 & 7.78 & 8.18 & Observed \\
\hline $\begin{array}{l}\text { Solomon } \\
\text { Islands }\end{array}$ & 2015 & Men & 9.48 & 9.07 & 9.89 & $\begin{array}{l}\text { ML } \\
\text { predicted }\end{array}$ \\
\hline $\begin{array}{l}\text { Solomon } \\
\text { Islands }\end{array}$ & 2015 & Men & 8.92 & 8.04 & 9.8 & Observed \\
\hline $\begin{array}{l}\text { Solomon } \\
\text { Islands }\end{array}$ & 2015 & Women & 7.78 & 7.47 & 8.1 & $\begin{array}{l}\mathrm{ML} \\
\text { predicted }\end{array}$ \\
\hline $\begin{array}{l}\text { Solomon } \\
\text { Islands }\end{array}$ & 2015 & Women & 7.4 & 6.67 & 8.13 & Observed \\
\hline Sudan & 2016 & Men & 9.02 & 8.52 & 9.52 & $\begin{array}{l}\mathrm{ML} \\
\text { predicted }\end{array}$ \\
\hline Sudan & 2016 & Men & 8.29 & 7.56 & 9.02 & Observed \\
\hline Sudan & 2016 & Women & 7.72 & 7.47 & 7.97 & $\begin{array}{l}\text { ML } \\
\text { predicted }\end{array}$ \\
\hline Sudan & 2016 & Women & 7.31 & 6.94 & 7.68 & Observed \\
\hline Tokelau & 2014 & Men & 10.13 & 9.42 & 10.83 & $\begin{array}{l}\mathrm{ML} \\
\text { predicted }\end{array}$ \\
\hline Tokelau & 2014 & Men & 10 & 9.28 & 10.72 & Observed \\
\hline Tokelau & 2014 & Women & 8.41 & 8.11 & 8.72 & $\begin{array}{l}\mathrm{ML} \\
\text { predicted }\end{array}$ \\
\hline Tokelau & 2014 & Women & 7.89 & 7.45 & 8.33 & Observed \\
\hline Turkmenistan & 2018 & Men & 9.45 & 9.32 & 9.58 & $\begin{array}{l}\mathrm{ML} \\
\text { predicted }\end{array}$ \\
\hline Turkmenistan & 2018 & Men & 8.87 & 8.72 & 9.01 & Observed \\
\hline Turkmenistan & 2018 & Women & 7.35 & 7.27 & 7.43 & $\begin{array}{l}\text { ML } \\
\text { predicted }\end{array}$ \\
\hline Turkmenistan & 2018 & Women & 6.79 & 6.7 & 6.89 & Observed \\
\hline Zambia & 2017 & Men & 8.82 & 8.68 & 8.96 & $\begin{array}{l}\mathrm{ML} \\
\text { predicted }\end{array}$ \\
\hline Zambia & 2017 & Men & 8.47 & 8.15 & 8.8 & Observed \\
\hline Zambia & 2017 & Women & 7.33 & 7.22 & 7.44 & $\begin{array}{l}\mathrm{ML} \\
\text { predicted }\end{array}$ \\
\hline Zambia & 2017 & Women & 7.14 & 6.96 & 7.32 & Observed \\
\hline
\end{tabular}


medRxiv preprint doi: https://doi.org/10.1101/2021.08.31.21262944; this version posted September 2, 2021. The copyright holder for this preprint (which was not certified by peer review) is the author/funder, who has granted medRxiv a license to display the preprint in It is made available under a CC-BY 4.0 International license.

Supplementary Table 4. Mean difference between observed and predicted salt intake by sex in each survey included in the ML model development.

\begin{tabular}{|c|c|c|c|c|c|c|c|}
\hline Country & Year & Sex & $\begin{array}{l}\text { Mean } \\
\text { difference } \\
\text { (g/day) }\end{array}$ & \begin{tabular}{|l} 
Mean \\
difference \\
(g/day) lower
\end{tabular} & $\begin{array}{l}\text { Mean } \\
\text { difference } \\
\text { (g/day) upper }\end{array}$ & Category & $P$ value \\
\hline Armenia & 2016 & Men & 0.03 & -0.21 & 0.26 & $\begin{array}{l}\text { Observed } \\
\text { vs } \\
\text { predicted }\end{array}$ & 0.7873 \\
\hline Armenia & 2016 & Women & -0.07 & -0.18 & 0.03 & $\begin{array}{l}\text { Observed } \\
\text { vs } \\
\text { predicted }\end{array}$ & 0.3432 \\
\hline Azerbaijan & 2017 & Men & 0.77 & 0.49 & 1.06 & $\begin{array}{l}\text { Observed } \\
\text { vs } \\
\text { predicted }\end{array}$ & $<0.0001$ \\
\hline Azerbaijan & 2017 & Women & 0.44 & 0.25 & 0.62 & $\begin{array}{l}\text { Observed } \\
\text { vs } \\
\text { predicted }\end{array}$ & $<0.0001$ \\
\hline Bangladesh & 2018 & Men & -0.12 & -0.26 & 0.02 & $\begin{array}{l}\text { Observed } \\
\text { vs } \\
\text { predicted }\end{array}$ & 0.0033 \\
\hline Bangladesh & 2018 & Women & -0.17 & -0.28 & -0.06 & $\begin{array}{l}\text { Observed } \\
\text { vs } \\
\text { predicted }\end{array}$ & 0.0002 \\
\hline Belarus & 2017 & Men & 0.18 & 0 & 0.37 & $\begin{array}{l}\text { Observed } \\
\text { vs } \\
\text { predicted }\end{array}$ & 0.0032 \\
\hline Belarus & 2017 & Women & 0.11 & $\mid-0.02$ & 0.24 & $\begin{array}{l}\text { Observed } \\
\text { vs } \\
\text { predicted }\end{array}$ & 0.004 \\
\hline Bhutan & 2014 & Men & 0.45 & 0.14 & 0.76 & $\begin{array}{l}\text { Observed } \\
\text { vs } \\
\text { predicted }\end{array}$ & $<0.0001$ \\
\hline Bhutan & 2014 & Women & 0.55 & 0.36 & 0.75 & $\begin{array}{l}\text { Observed } \\
\text { vs } \\
\text { predicted }\end{array}$ & $<0.0001$ \\
\hline Bhutan & 2019 & Men & -0.31 & -0.53 & -0.09 & $\begin{array}{l}\text { Observed } \\
\text { vs } \\
\text { predicted }\end{array}$ & $<0.0001$ \\
\hline Bhutan & 2019 & Women & -0.09 & -0.25 & 0.07 & $\begin{array}{l}\text { Observed } \\
\text { vs } \\
\text { predicted }\end{array}$ & 0.108 \\
\hline $\begin{array}{l}\text { Brunei } \\
\text { Darussalam }\end{array}$ & 2016 & Men & -0.55 & -0.8 & -0.29 & $\begin{array}{l}\text { Observed } \\
\text { vs } \\
\text { predicted }\end{array}$ & $<0.0001$ \\
\hline \begin{tabular}{|l|} 
Brunei \\
Darussalam
\end{tabular} & 2016 & Women & -0.71 & -0.87 & -0.54 & $\begin{array}{l}\text { Observed } \\
\text { vs } \\
\text { predicted }\end{array}$ & $<0.0001$ \\
\hline
\end{tabular}


medRxiv preprint doi: https://doi.org/10.1101/2021.08.31.21262944; this version posted September 2, 2021. The copyright holder for this preprint (which was not certified by peer review) is the author/funder, who has granted medRxiv a license to display the preprint in

It is made available under a CC-BY 4.0 International license.

\begin{tabular}{|c|c|c|c|c|c|c|c|}
\hline Jordan & 2019 & Men & 0.66 & 0.01 & 1.32 & $\begin{array}{l}\text { Observed } \\
\text { vs } \\
\text { predicted }\end{array}$ & 0.75 \\
\hline Jordan & 2019 & Women & 0.4 & 0.05 & 0.75 & $\begin{array}{l}\text { Observed } \\
\text { vs } \\
\text { predicted }\end{array}$ & 0.0513 \\
\hline Lebanon & 2017 & Men & -0.74 & -1.27 & -0.22 & $\begin{array}{l}\text { Observed } \\
\text { vs } \\
\text { predicted }\end{array}$ & 0.2274 \\
\hline Lebanon & 2017 & Women & -0.11 & -0.68 & 0.47 & $\begin{array}{l}\text { Observed } \\
\text { vs } \\
\text { predicted }\end{array}$ & 0.4273 \\
\hline Malawi & 2017 & Men & 1.39 & 0.9 & 1.88 & $\begin{array}{l}\text { Observed } \\
\text { vs } \\
\text { predicted }\end{array}$ & $<0.0001$ \\
\hline Malawi & 2017 & Women & 1.02 & 0.7 & 1.35 & $\begin{array}{l}\text { Observed } \\
\text { vs } \\
\text { predicted }\end{array}$ & $<0.0001$ \\
\hline Mongolia & 2013 & Men & 0.06 & -0.3 & 0.43 & $\begin{array}{l}\text { Observed } \\
\text { vs } \\
\text { predicted }\end{array}$ & 0.4277 \\
\hline Mongolia & 2013 & Women & -0.12 & -0.3 & 0.06 & $\begin{array}{l}\text { Observed } \\
\text { vs } \\
\text { predicted }\end{array}$ & 0.3048 \\
\hline Mongolia & 2019 & Men & 0.3 & 0.16 & 0.43 & $\begin{array}{l}\text { Observed } \\
\text { vs } \\
\text { predicted }\end{array}$ & $<0.0001$ \\
\hline Mongolia & 2019 & Women & -0.12 & -0.21 & -0.03 & $\begin{array}{l}\text { Observed } \\
\text { vs } \\
\text { predicted }\end{array}$ & 0.0009 \\
\hline Morocco & 2017 & Men & -0.22 & -0.4 & -0.03 & $\begin{array}{l}\text { Observed } \\
\text { vs } \\
\text { predicted }\end{array}$ & 0.0171 \\
\hline Morocco & 2017 & Women & -0.15 & -0.25 & -0.04 & $\begin{array}{l}\text { Observed } \\
\text { vs } \\
\text { predicted }\end{array}$ & 0.0095 \\
\hline Nepal & 2019 & Men & 0.81 & 0.5 & 1.13 & $\begin{array}{l}\text { Observed } \\
\text { vs } \\
\text { predicted }\end{array}$ & $<0.0001$ \\
\hline Nepal & 2019 & Women & 0.71 & 0.54 & 0.88 & $\begin{array}{l}\text { Observed } \\
\text { vs } \\
\text { predicted }\end{array}$ & $<0.0001$ \\
\hline $\begin{array}{l}\text { Solomon } \\
\text { Islands }\end{array}$ & 2015 & Men & -0.56 & $\mid-1.3$ & 0.19 & $\begin{array}{l}\text { Observed } \\
\text { vs } \\
\text { predicted }\end{array}$ & 0.0358 \\
\hline $\begin{array}{l}\text { Solomon } \\
\text { Islands }\end{array}$ & 2015 & Women & -0.39 & -1.05 & 0.28 & $\begin{array}{l}\text { Observed } \\
\text { vs } \\
\text { predicted }\end{array}$ & 0.1386 \\
\hline
\end{tabular}


medRxiv preprint doi: https://doi.org/10.1101/2021.08.31.21262944; this version posted September 2, 2021. The copyright holder for this preprint (which was not certified by peer review) is the author/funder, who has granted medRxiv a license to display the preprint in It is made available under a CC-BY 4.0 International license .

\begin{tabular}{|l|l|l|l|l|l|l|l|}
\hline Sudan & 2016 & Men & -0.73 & -1.2 & -0.27 & $\begin{array}{l}\text { Observed } \\
\text { vs } \\
\text { predicted }\end{array}$ & 0.0018 \\
\hline Sudan & 2016 & Women & -0.41 & -0.66 & -0.16 & $\begin{array}{l}\text { Observed } \\
\text { vs } \\
\text { predicted }\end{array}$ & $<0.0001$ \\
\hline Tokelau & 2014 & Men & -0.13 & -0.69 & 0.44 & $\begin{array}{l}\text { Observed } \\
\text { vs } \\
\text { predicted }\end{array}$ & 0.9361 \\
\hline Tokelau & 2014 & Women & -0.52 & -1.07 & 0.02 & $\begin{array}{l}\text { Observed } \\
\text { vs } \\
\text { predicted }\end{array}$ & 0.279 \\
\hline Turkmenistan & 2018 & Men & -0.59 & -0.68 & -0.5 & $\begin{array}{l}\text { Observed } \\
\text { vs } \\
\text { predicted }\end{array}$ & $<0.0001$ \\
\hline Turkmenistan & 2018 & Women & -0.56 & -0.62 & -0.49 & $\begin{array}{l}\text { Observed } \\
\text { vs } \\
\text { predicted }\end{array}$ & $<0.0001$ \\
\hline Zambia & 2017 & Men & -0.35 & -0.65 & -0.05 & $\begin{array}{l}\text { Observed } \\
\text { vs } \\
\text { predicted }\end{array}$ & 0.0004 \\
\hline Zambia & 2017 & Women & -0.19 & -0.34 & -0.04 & $\begin{array}{l}\text { Observed } \\
\text { vs } \\
\text { predicted }\end{array}$ & 0.0001 \\
\hline
\end{tabular}


medRxiv preprint doi: https://doi.org/10.1101/2021.08.31.21262944; this version posted September 2, 2021. The copyright holder for this preprint (which was not certified by peer review) is the author/funder, who has granted medRxiv a license to display the preprint in perpetuity.

It is made available under a CC-BY 4.0 International license .

Supplementary Table 5. Observed mean salt intake (g/day) by equation and sex in each survey included in the ML model development.

\begin{tabular}{|c|c|c|c|c|c|c|}
\hline Country & Year & Sex & \begin{tabular}{|l} 
Mean salt \\
intake \\
(g/day)
\end{tabular} & $\begin{array}{l}\text { Mean salt } \\
\text { intake (g/day) } \\
\text { lower }\end{array}$ & $\begin{array}{l}\text { Mean salt } \\
\text { intake (g/day) } \\
\text { upper }\end{array}$ & Category \\
\hline Armenia & 2016 & Men & 9.44 & 9.05 & 9.83 & Observed_intersalt \\
\hline Armenia & 2016 & Men & 13.79 & 13.03 & 14.55 & Observed_kawasaki \\
\hline Armenia & 2016 & Men & 9.87 & 9.43 & 10.3 & Observed_tanaka \\
\hline Armenia & 2016 & Men & 12.31 & 11.84 & 12.78 & Observed_toft \\
\hline Armenia & 2016 & Women & 7.47 & 7.28 & 7.66 & Observed_intersalt \\
\hline Armenia & 2016 & Women & 12.18 & 11.67 & 12.69 & Observed_kawasaki \\
\hline Armenia & 2016 & Women & 9.81 & 9.47 & 10.15 & Observed_tanaka \\
\hline Armenia & 2016 & Women & 8.34 & 8.2 & 8.47 & Observed_toft \\
\hline Azerbaijan & 2017 & Men & 10.28 & 9.99 & 10.58 & Observed_intersalt \\
\hline Azerbaijan & 2017 & Men & 14.92 & 14.28 & 15.55 & Observed_kawasaki \\
\hline Azerbaijan & 2017 & Men & 10.37 & 10.02 & 10.72 & Observed_tanaka \\
\hline Azerbaijan & 2017 & Men & 12.88 & 12.5 & 13.25 & Observed_toft \\
\hline Azerbaijan & 2017 & Women & 8.01 & 7.77 & 8.25 & Observed_intersalt \\
\hline Azerbaijan & 2017 & Women & 12.48 & 11.92 & 13.03 & Observed_kawasaki \\
\hline Azerbaijan & 2017 & Women & 10.05 & 9.7 & 10.4 & Observed_tanaka \\
\hline Azerbaijan & 2017 & Women & 8.4 & 8.25 & 8.55 & Observed_toft \\
\hline Bangladesh & 2018 & Men & 8.56 & 8.4 & 8.72 & Observed_intersalt \\
\hline Bangladesh & 2018 & Men & 12.9 & 12.61 & 13.19 & Observed_kawasaki \\
\hline Bangladesh & 2018 & Men & 8.94 & 8.77 & 9.1 & Observed_tanaka \\
\hline Bangladesh & 2018 & Men & 11.81 & 11.63 & 11.99 & Observed_toft \\
\hline Bangladesh & 2018 & Women & 7.24 & 7.12 & 7.35 & Observed_intersalt \\
\hline Bangladesh & 2018 & Women & 11.91 & 11.62 & 12.19 & Observed_kawasaki \\
\hline Bangladesh & 2018 & Women & 8.91 & 8.73 & 9.08 & Observed_tanaka \\
\hline Bangladesh & 2018 & Women & 8.28 & 8.2 & 8.36 & Observed_toft \\
\hline Belarus & 2017 & Men & 9.92 & 9.69 & 10.14 & Observed_intersalt \\
\hline Belarus & 2017 & Men & 13.88 & 13.51 & 14.25 & Observed_kawasaki \\
\hline Belarus & 2017 & Men & 9.97 & 9.76 & 10.19 & Observed_tanaka \\
\hline Belarus & 2017 & Men & 12.24 & 12.01 & 12.47 & Observed_toft \\
\hline Belarus & 2017 & Women & 7.56 & 7.41 & 7.71 & Observed_intersalt \\
\hline Belarus & 2017 & Women & 11.61 & 11.31 & 11.92 & Observed_kawasaki \\
\hline Belarus & 2017 & Women & 9.67 & 9.47 & 9.87 & Observed_tanaka \\
\hline Belarus & 2017 & Women & 8.14 & 8.06 & 8.23 & Observed_toft \\
\hline Bhutan & 2014 & Men & 9.49 & 9.12 & 9.86 & Observed_intersalt \\
\hline
\end{tabular}


medRxiv preprint doi: https://doi.org/10.1101/2021.08.31.21262944; this version posted September 2, 2021. The copyright holder for this preprint (which was not certified by peer review) is the author/funder, who has granted medRxiv a license to display the preprint in perpetuity.

It is made available under a CC-BY 4.0 International license .

\begin{tabular}{|c|c|c|c|c|c|c|}
\hline Bhutan & 2014 & Men & 14.44 & 13.65 & 15.23 & Observed_kawasaki \\
\hline Bhutan & 2014 & Men & 9.77 & 9.33 & 10.2 & Observed_tanaka \\
\hline Bhutan & 2014 & Men & 12.68 & 12.2 & 13.16 & Observed_toft \\
\hline Bhutan & 2014 & Women & 8.11 & 7.88 & 8.34 & Observed_intersalt \\
\hline Bhutan & 2014 & Women & 14.11 & 13.57 & 14.66 & Observed_kawasaki \\
\hline Bhutan & 2014 & Women & 10.53 & 10.19 & 10.87 & Observed_tanaka \\
\hline Bhutan & 2014 & Women & 8.81 & 8.67 & 8.95 & Observed_toft \\
\hline Bhutan & 2019 & Men & 8.83 & 8.6 & 9.06 & Observed_intersalt \\
\hline Bhutan & 2019 & Men & 12.34 & 11.86 & 12.82 & Observed_kawasaki \\
\hline Bhutan & 2019 & Men & 8.51 & 8.27 & 8.75 & Observed_tanaka \\
\hline Bhutan & 2019 & Men & 11.36 & 11.06 & 11.65 & Observed_toft \\
\hline Bhutan & 2019 & Women & 7.42 & 7.24 & 7.59 & Observed_intersalt \\
\hline Bhutan & 2019 & Women & 11.63 & 11.23 & 12.02 & Observed_kawasaki \\
\hline Bhutan & 2019 & Women & 8.91 & 8.66 & 9.15 & Observed_tanaka \\
\hline Bhutan & 2019 & Women & 8.2 & 8.09 & 8.3 & Observed_toft \\
\hline $\begin{array}{l}\text { Brunei } \\
\text { Darussalam }\end{array}$ & 2016 & Men & 9.37 & 9.07 & 9.67 & Observed_intersalt \\
\hline $\begin{array}{l}\text { Brunei } \\
\text { Darussalam }\end{array}$ & 2016 & Men & 11.95 & 11.52 & 12.38 & Observed_kawasaki \\
\hline $\begin{array}{l}\text { Brunei } \\
\text { Darussalam }\end{array}$ & 2016 & Men & 8.44 & 8.2 & 8.68 & Observed_tanaka \\
\hline $\begin{array}{l}\text { Brunei } \\
\text { Darussalam }\end{array}$ & 2016 & Men & 11.09 & 10.82 & 11.36 & Observed_toft \\
\hline $\begin{array}{l}\text { Brunei } \\
\text { Darussalam }\end{array}$ & 2016 & Women & 7.1 & 6.87 & 7.32 & Observed_intersalt \\
\hline $\begin{array}{l}\text { Brunei } \\
\text { Darussalam }\end{array}$ & 2016 & Women & 10 & 9.62 & 10.38 & Observed_kawasaki \\
\hline $\begin{array}{l}\text { Brunei } \\
\text { Darussalam }\end{array}$ & 2016 & Women & 8.1 & 7.85 & 8.36 & Observed_tanaka \\
\hline $\begin{array}{l}\text { Brunei } \\
\text { Darussalam }\end{array}$ & 2016 & Women & 7.75 & 7.63 & 7.86 & Observed_toft \\
\hline Jordan & 2019 & Men & 10.26 & 9.65 & 10.87 & Observed_intersalt \\
\hline Jordan & 2019 & Men & 13.76 & 12.59 & 14.93 & Observed_kawasaki \\
\hline Jordan & 2019 & Men & 9.71 & 9.12 & 10.3 & Observed_tanaka \\
\hline Jordan & 2019 & Men & 12.18 & 11.51 & 12.84 & Observed_toft \\
\hline Jordan & 2019 & Women & 8.4 & 8.03 & 8.77 & Observed_intersalt \\
\hline Jordan & 2019 & Women & 12.28 & 11.58 & 12.98 & Observed_kawasaki \\
\hline Jordan & 2019 & Women & 9.81 & 9.36 & 10.26 & Observed_tanaka \\
\hline Jordan & 2019 & Women & 8.37 & 8.18 & 8.57 & Observed_toft \\
\hline Lebanon & 2017 & Men & 9.33 & 8.88 & 9.78 & Observed_intersalt \\
\hline Lebanon & 2017 & Men & 12.79 & 11.35 & 14.23 & Observed_kawasaki \\
\hline
\end{tabular}


medRxiv preprint doi: https://doi.org/10.1101/2021.08.31.21262944; this version posted September 2, 2021. The copyright holder for this preprint (which was not certified by peer review) is the author/funder, who has granted medRxiv a license to display the preprint in It is made available under a CC-BY 4.0 International license.

\begin{tabular}{|c|c|c|c|c|c|c|}
\hline Lebanon & 2017 & Men & 9.21 & 8.41 & 10 & Observed_tanaka \\
\hline Lebanon & 2017 & Men & 11.5 & 10.6 & 12.4 & Observed_toft \\
\hline Lebanon & 2017 & Women & 7.53 & 6.93 & 8.13 & Observed_intersalt \\
\hline Lebanon & 2017 & Women & 11.48 & 10.08 & 12.88 & Observed_kawasaki \\
\hline Lebanon & 2017 & Women & 9.44 & 8.44 & 10.44 & Observed_tanaka \\
\hline Lebanon & 2017 & Women & 8.06 & 7.58 & 8.54 & Observed_toft \\
\hline Malawi & 2017 & Men & 10.09 & 9.61 & 10.57 & Observed_intersalt \\
\hline Malawi & 2017 & Men & 14.37 & 13.72 & 15.02 & Observed_kawasaki \\
\hline Malawi & 2017 & Men & 9.62 & 9.26 & 9.98 & Observed_tanaka \\
\hline Malawi & 2017 & Men & 12.68 & 12.3 & 13.07 & Observed_toft \\
\hline Malawi & 2017 & Women & 8.4 & 8.07 & 8.74 & Observed_intersalt \\
\hline Malawi & 2017 & Women & 13.74 & 12.87 & 14.6 & Observed_kawasaki \\
\hline Malawi & 2017 & Women & 10.32 & 9.8 & 10.84 & Observed_tanaka \\
\hline Malawi & 2017 & Women & 8.69 & 8.48 & 8.91 & Observed_toft \\
\hline Mongolia & 2013 & Men & 9.71 & 9.31 & 10.1 & Observed_intersalt \\
\hline Mongolia & 2013 & Men & 13.25 & 12.63 & 13.87 & Observed_kawasaki \\
\hline Mongolia & 2013 & Men & 9.37 & 9.04 & 9.7 & Observed_tanaka \\
\hline Mongolia & 2013 & Men & 11.96 & 11.57 & 12.35 & Observed_toft \\
\hline Mongolia & 2013 & Women & 7.72 & 7.52 & 7.92 & Observed_intersalt \\
\hline Mongolia & 2013 & Women & 11.65 & 11.11 & 12.2 & Observed_kawasaki \\
\hline Mongolia & 2013 & Women & 9.37 & 9.01 & 9.73 & Observed_tanaka \\
\hline Mongolia & 2013 & Women & 8.18 & 8.03 & 8.34 & Observed_toft \\
\hline Mongolia & 2019 & Men & 9.71 & 9.55 & 9.86 & Observed_intersalt \\
\hline Mongolia & 2019 & Men & 14.77 & 14.43 & 15.1 & Observed_kawasaki \\
\hline Mongolia & 2019 & Men & 10.09 & 9.91 & 10.27 & Observed_tanaka \\
\hline Mongolia & 2019 & Men & 12.81 & 12.61 & 13 & Observed_toft \\
\hline Mongolia & 2019 & Women & 7.43 & 7.31 & 7.56 & Observed_intersalt \\
\hline Mongolia & 2019 & Women & 11.97 & 11.68 & 12.25 & Observed_kawasaki \\
\hline Mongolia & 2019 & Women & 9.54 & 9.35 & 9.73 & Observed_tanaka \\
\hline Mongolia & 2019 & Women & 8.27 & 8.19 & 8.35 & Observed_toft \\
\hline Morocco & 2017 & Men & 9.04 & 8.82 & 9.26 & Observed_intersalt \\
\hline Morocco & 2017 & Men & 13.14 & 12.7 & 13.58 & Observed_kawasaki \\
\hline Morocco & 2017 & Men & 9.41 & 9.16 & 9.66 & Observed_tanaka \\
\hline Morocco & 2017 & Men & 11.82 & 11.55 & 12.09 & Observed_toft \\
\hline Morocco & 2017 & Women & 7.5 & 7.39 & 7.62 & Observed_intersalt \\
\hline Morocco & 2017 & Women & 11.74 & 11.43 & 12.04 & Observed_kawasaki \\
\hline Morocco & 2017 & Women & 9.5 & 9.3 & 9.69 & Observed_tanaka \\
\hline Morocco & 2017 & Women & 8.19 & 8.11 & 8.27 & Observed_toft \\
\hline
\end{tabular}


medRxiv preprint doi: https://doi.org/10.1101/2021.08.31.21262944; this version posted September 2, 2021. The copyright holder for this preprint (which was not certified by peer review) is the author/funder, who has granted medRxiv a license to display the preprint in perpetuity.

It is made available under a CC-BY 4.0 International license .

\begin{tabular}{|c|c|c|c|c|c|c|}
\hline Nepal & 2019 & Men & 9.63 & 9.25 & 10 & Observed_intersalt \\
\hline Nepal & 2019 & Men & 16.78 & 15.86 & 17.69 & Observed_kawasaki \\
\hline Nepal & 2019 & Men & 10.82 & 10.34 & 11.29 & Observed_tanaka \\
\hline Nepal & 2019 & Men & 14.15 & 13.63 & 14.68 & Observed_toft \\
\hline Nepal & 2019 & Women & 7.98 & 7.78 & 8.18 & Observed_intersalt \\
\hline Nepal & 2019 & Women & 15.76 & 15.21 & 16.32 & Observed_kawasaki \\
\hline Nepal & 2019 & Women & 11.15 & 10.83 & 11.46 & Observed_tanaka \\
\hline Nepal & 2019 & Women & 9.21 & 9.09 & 9.34 & Observed_toft \\
\hline $\begin{array}{l}\text { Solomon } \\
\text { Islands }\end{array}$ & 2015 & Men & 8.92 & 8.04 & 9.8 & Observed_intersalt \\
\hline $\begin{array}{l}\text { Solomon } \\
\text { Islands }\end{array}$ & 2015 & Men & 12.07 & 10.21 & 13.92 & Observed_kawasaki \\
\hline $\begin{array}{l}\text { Solomon } \\
\text { Islands }\end{array}$ & 2015 & Men & 8.63 & 7.55 & 9.7 & Observed_tanaka \\
\hline $\begin{array}{l}\text { Solomon } \\
\text { Islands }\end{array}$ & 2015 & Men & 11.14 & 9.94 & 12.33 & Observed_toft \\
\hline $\begin{array}{l}\text { Solomon } \\
\text { Islands }\end{array}$ & 2015 & Women & 7.4 & 6.67 & 8.13 & Observed_intersalt \\
\hline $\begin{array}{l}\text { Solomon } \\
\text { Islands }\end{array}$ & 2015 & Women & 13.18 & 10.5 & 15.86 & Observed_kawasaki \\
\hline $\begin{array}{l}\text { Solomon } \\
\text { Islands }\end{array}$ & 2015 & Women & 9.96 & 8.3 & 11.63 & Observed_tanaka \\
\hline $\begin{array}{l}\text { Solomon } \\
\text { Islands }\end{array}$ & 2015 & Women & 8.44 & 7.74 & 9.15 & Observed_toft \\
\hline Sudan & 2016 & Men & 8.29 & 7.56 & 9.02 & Observed_intersalt \\
\hline Sudan & 2016 & Men & 11.27 & 10.41 & 12.13 & Observed_kawasaki \\
\hline Sudan & 2016 & Men & 8.19 & 7.66 & 8.73 & Observed_tanaka \\
\hline Sudan & 2016 & Men & 10.6 & 10.04 & 11.15 & Observed_toft \\
\hline Sudan & 2016 & Women & 7.31 & 6.94 & 7.68 & Observed_intersalt \\
\hline Sudan & 2016 & Women & 10.36 & 9.8 & 10.93 & Observed_kawasaki \\
\hline Sudan & 2016 & Women & 8.72 & 8.31 & 9.12 & Observed_tanaka \\
\hline Sudan & 2016 & Women & 7.81 & 7.65 & 7.98 & Observed_toft \\
\hline Tokelau & 2014 & Men & 10 & 9.28 & 10.72 & Observed_intersalt \\
\hline Tokelau & 2014 & Men & 15.6 & 14.19 & 17 & Observed_kawasaki \\
\hline Tokelau & 2014 & Men & 10.89 & 10.05 & 11.73 & Observed_tanaka \\
\hline Tokelau & 2014 & Men & 13.19 & 12.36 & 14.03 & Observed_toft \\
\hline Tokelau & 2014 & Women & 7.89 & 7.45 & 8.33 & Observed_intersalt \\
\hline Tokelau & 2014 & Women & 12.38 & 11.16 & 13.59 & Observed_kawasaki \\
\hline Tokelau & 2014 & Women & 10.22 & 9.46 & 10.98 & Observed_tanaka \\
\hline Tokelau & 2014 & Women & 8.38 & 8.07 & 8.68 & Observed_toft \\
\hline Turkmenistan & 2018 & Men & 8.87 & 8.72 & 9.01 & Observed_intersalt \\
\hline
\end{tabular}


medRxiv preprint doi: https://doi.org/10.1101/2021.08.31.21262944; this version posted September 2, 2021. The copyright holder for this preprint (which was not certified by peer review) is the author/funder, who has granted medRxiv a license to display the preprint in It is made available under a CC-BY 4.0 International license .

\begin{tabular}{|l|l|l|l|l|l|l|}
\hline Turkmenistan & 2018 & Men & 12.05 & 11.85 & 12.25 & Observed_kawasaki \\
\hline Turkmenistan & 2018 & Men & 8.8 & 8.69 & 8.92 & Observed_tanaka \\
\hline Turkmenistan & 2018 & Men & 11.16 & 11.03 & 11.28 & Observed_toft \\
\hline Turkmenistan & 2018 & Women & 6.79 & 6.7 & 6.89 & Observed_intersalt \\
\hline Turkmenistan & 2018 & Women & 10.07 & 9.9 & 10.24 & Observed_kawasaki \\
\hline Turkmenistan & 2018 & Women & 8.54 & 8.41 & 8.67 & Observed_tanaka \\
\hline Turkmenistan & 2018 & Women & 7.77 & 7.72 & 7.82 & Observed_toft \\
\hline Zambia & 2017 & Men & 8.47 & 8.15 & 8.8 & Observed_intersalt \\
\hline Zambia & 2017 & Men & 12.52 & 11.85 & 13.19 & Observed_kawasaki \\
\hline Zambia & 2017 & Men & 8.66 & 8.31 & 9.02 & Observed_tanaka \\
\hline Zambia & 2017 & Men & 11.37 & 10.95 & 11.78 & Observed_toft \\
\hline Zambia & 2017 & Women & 7.14 & 6.96 & 7.32 & Observed_intersalt \\
\hline Zambia & 2017 & Women & 11.47 & 10.98 & 11.97 & Observed_kawasaki \\
\hline Zambia & 2017 & Women & 9.02 & 8.71 & 9.33 & Observed_tanaka \\
\hline Zambia & 2017 & Women & 8.09 & 7.95 & 8.23 & Observed_toft \\
\hline
\end{tabular}


Supplementary Table 6. Weighted distribution of predictors in each of the 49 national surveys included in the application of the model herein developed.

\begin{tabular}{|c|c|c|c|c|c|c|c|c|c|c|}
\hline Country & Year & Region & $\begin{array}{l}\text { Sample } \\
\text { size }\end{array}$ & $\begin{array}{l}\text { Mean } \\
\text { age } \\
\text { (years) }\end{array}$ & $\begin{array}{l}\text { Age } \\
\text { range } \\
\text { (years) }\end{array}$ & $\begin{array}{l}\text { Proportion } \\
\text { of men }(\%)\end{array}$ & $\begin{array}{l}\text { Mean, } \\
\text { minimum and } \\
\text { maximum } \\
\text { values of SBP } \\
(\mathrm{mmHg})\end{array}$ & $\begin{array}{l}\text { Mean, } \\
\text { minimum and } \\
\text { maximum } \\
\text { values of DBP } \\
(\mathrm{mmHg})\end{array}$ & $\begin{array}{l}\text { Mean, } \\
\text { minimum and } \\
\text { maximum } \\
\text { values of } \\
\text { weight }(\mathbf{k g})\end{array}$ & $\begin{array}{l}\text { Mean, } \\
\text { minimum and } \\
\text { maximum } \\
\text { values of } \\
\text { height }(\mathrm{m})\end{array}$ \\
\hline Algeria & 2017 & Africa & 6536 & 38 & $18-69$ & 51.7 & $126.6(77-227)$ & $75.2(32-137)$ & $73.3(25-174)$ & $\begin{array}{l}1.67(1.02- \\
2.05)\end{array}$ \\
\hline $\begin{array}{l}\text { American } \\
\text { Samoa }\end{array}$ & 2004 & Americas & 2042 & 40 & $25-64$ & 50.3 & $\begin{array}{l}130.7 \text { (84.5- } \\
230.5)\end{array}$ & $\begin{array}{l}82.4(46.5- \\
134.5)\end{array}$ & $\begin{array}{l}100.4 \text { (38.6- } \\
219.1)\end{array}$ & $\begin{array}{l}1.69(1.36- \\
2.19)\end{array}$ \\
\hline Bahamas & 2012 & Americas & 1400 & 42 & $24-64$ & 49.9 & $\begin{array}{l}127.4(73- \\
248.5)\end{array}$ & $\begin{array}{l}81.6(32.5- \\
139.5) \\
\end{array}$ & \begin{tabular}{|l}
$84.8(27.9-$ \\
$184.9)$
\end{tabular} & $\begin{array}{l}1.67(1.15- \\
2.03)\end{array}$ \\
\hline Barbados & 2007 & Americas & 282 & 43 & $25-69$ & 51.9 & $121.9(86-191)$ & $80.1(55-115)$ & $\begin{array}{l}77.5 \text { (40.6- } \\
232.1)\end{array}$ & $\begin{array}{l}1.67(1.17- \\
1.93)\end{array}$ \\
\hline Benin & 2015 & Africa & 4841 & 34 & $18-69$ & 49.6 & $\begin{array}{l}125.8(74.5- \\
254.5)\end{array}$ & $81.6(45-142.5)$ & $62.3(30-167)$ & $\begin{array}{l}1.64(1.21- \\
1.98)\end{array}$ \\
\hline Botswana & 2014 & Africa & 3894 & 33 & $15-69$ & 52.1 & $\begin{array}{l}127.5(84.5- \\
262.5)\end{array}$ & $80(47-148.5)$ & $\begin{array}{l}63.9(31.7- \\
171.1) \\
\end{array}$ & $1.66(1.02-2)$ \\
\hline $\begin{array}{l}\text { British Virgin } \\
\text { Islands }\end{array}$ & 2009 & Americas & 1067 & 43 & $25-64$ & 54.1 & $\begin{array}{l}130.5(81- \\
225.5)\end{array}$ & $80.3(47.5-126)$ & $\begin{array}{l}83.2(39.6- \\
176.9)\end{array}$ & $1.7(1.14-2.26)$ \\
\hline Cabo Verde & 2007 & Africa & 1723 & 38 & $25-64$ & 50.3 & $\begin{array}{l}133.3(86- \\
233.5)\end{array}$ & $79.7(47.5-140)$ & $68.3(35-150)$ & $\begin{array}{l}1.68(1.23- \\
1.96)\end{array}$ \\
\hline Cambodia & 2010 & $\begin{array}{l}\text { Western } \\
\text { Pacific }\end{array}$ & 5223 & 40 & $25-64$ & 49.4 & $\begin{array}{l}116.2 \text { (70.5- } \\
225.5)\end{array}$ & $72.4(41.5-138)$ & $53.7(21.1-111)$ & $\begin{array}{l}1.57(1.24- \\
1.85)\end{array}$ \\
\hline Cayman Islands & 2012 & Americas & 1229 & 42 & $24-64$ & 50.7 & $\begin{array}{l}124.7 \text { (84- } \\
207.5)\end{array}$ & 76 (46.5-127) & $82.3(31-196)$ & $1.69(1-2.1)$ \\
\hline
\end{tabular}




\begin{tabular}{|c|c|c|c|c|c|c|c|c|c|c|}
\hline Comoros & 2011 & Africa & 5029 & 39 & $25-64$ & 52.6 & $\begin{array}{l}127.6(82.5- \\
236.5)\end{array}$ & 78.5 (48.5-144) & $64.2(23.5-166)$ & $1.61(1-2.15)$ \\
\hline Cook Islands & 2015 & $\begin{array}{l}\text { Western } \\
\text { Pacific }\end{array}$ & 879 & 39 & $18-64$ & 46.5 & $128(91.5-194)$ & 78.8 (45-118.5) & $\begin{array}{l}98.6(49.1- \\
205.1)\end{array}$ & $\begin{array}{l}1.69(1.07- \\
1.96)\end{array}$ \\
\hline Ecuador & 2018 & Americas & 4466 & 40 & $18-69$ & 49.4 & $\begin{array}{l}119.9(78- \\
220.5)\end{array}$ & $76(42-130)$ & $\begin{array}{l}69.2(33.4- \\
198.4)\end{array}$ & $\begin{array}{l}1.59(1.24- \\
1.93)\end{array}$ \\
\hline Eritrea & 2010 & Africa & 5651 & 42 & $25-69$ & 17.2 & $\begin{array}{l}117(71.5- \\
230.5)\end{array}$ & $\begin{array}{l}74.3(45.5- \\
130.5)\end{array}$ & $51.8(28.1-99.1)$ & $1.6(1.16-1.89)$ \\
\hline Eswatini & 2014 & Africa & 3042 & 31 & $15-69$ & 47.4 & $\begin{array}{l}124.3(72- \\
251.5)\end{array}$ & $79.7(42-149.5)$ & $\begin{array}{l}67.8(22.2- \\
227.6)\end{array}$ & $\begin{array}{l}1.63(1.01- \\
2.02)\end{array}$ \\
\hline Ethiopia & 2015 & Africa & 9270 & 31 & $15-69$ & 56.1 & $\begin{array}{l}119.7(71- \\
250.5)\end{array}$ & $77.7(30-142)$ & $54.4(20-99.5)$ & $1.63(1.05-2)$ \\
\hline Fiji & 2011 & $\begin{array}{l}\text { Western } \\
\text { Pacific }\end{array}$ & 2492 & 42 & $25-64$ & 51 & $\begin{array}{l}130.3(84.5- \\
228)\end{array}$ & $80.2(39-143)$ & $\begin{array}{l}78.6(30.3- \\
198.1)\end{array}$ & $\begin{array}{l}1.68(1.03- \\
1.94)\end{array}$ \\
\hline $\begin{array}{l}\text { French } \\
\text { Polynesia }\end{array}$ & 2010 & $\begin{array}{l}\text { Western } \\
\text { Pacific }\end{array}$ & 2239 & 36 & $18-64$ & 50.7 & $\begin{array}{l}125(85.5- \\
230.5)\end{array}$ & $79.4(48-149.5)$ & $86.2(41-193)$ & $1.7(1.41-2)$ \\
\hline Gambia & 2010 & Africa & 3496 & 38 & $25-64$ & 50.4 & $130.4(85-252)$ & $80.3(44-143.5)$ & $\begin{array}{l}64.8(26.5- \\
168.9)\end{array}$ & $1.64(1-2)$ \\
\hline Grenada & 2011 & Americas & 1055 & 41 & $25-64$ & 50.7 & $\begin{array}{l}130.5(71- \\
212.5)\end{array}$ & 80.5 (49.5-128) & $\begin{array}{l}77.6(40.8- \\
158.8)\end{array}$ & $1.7(1.32-2.49)$ \\
\hline Guyana & 2016 & Americas & 2625 & 37 & $18-69$ & 52 & $\begin{array}{l}125.7 \text { (73.5- } \\
245)\end{array}$ & 77.6 (37-149) & $69.9(26.4-198)$ & $\begin{array}{l}1.63(1.01- \\
2.07)\end{array}$ \\
\hline Iraq & 2015 & $\begin{array}{l}\text { Eastern } \\
\text { Mediterranean } \\
\end{array}$ & 3655 & 35 & $18-69$ & 53.6 & $\begin{array}{l}128.1 \text { (78.5- } \\
225)\end{array}$ & $82.7(45-150)$ & $\begin{array}{l}76.5(36.6- \\
187.2) \\
\end{array}$ & $\begin{array}{l}1.65(1.01- \\
1.97) \\
\end{array}$ \\
\hline Kenya & 2015 & Africa & 4270 & 34 & $16-69$ & 50.6 & $\begin{array}{l}124.7(76.5- \\
262)\end{array}$ & 80.8 (46.5-146) & $63.2(30-171.3)$ & $\begin{array}{l}1.65(1.01- \\
1.95)\end{array}$ \\
\hline Kiribati & 2016 & $\begin{array}{l}\text { Western } \\
\text { Pacific }\end{array}$ & 1240 & 40 & $18-69$ & 42.8 & $128(85-219.5)$ & 84.6 (49-147.5) & $81.1(30-219)$ & $\begin{array}{l}1.64(1.22- \\
1.89)\end{array}$ \\
\hline Kuwait & 2014 & \begin{tabular}{|l} 
Eastern \\
Mediterranean
\end{tabular} & 2871 & 36 & $18-69$ & 49.5 & $120.4(70-240)$ & $77.4(50-130)$ & 80.5 (37.3-195) & $\begin{array}{l}1.65(1.04- \\
1.96)\end{array}$ \\
\hline
\end{tabular}




\begin{tabular}{|c|c|c|c|c|c|c|c|c|c|c|}
\hline Kyrgyzstan & 2013 & \begin{tabular}{|l} 
Eastern \\
Mediterranean
\end{tabular} & 2539 & 41 & $25-64$ & 51.9 & $\begin{array}{l}133.2 \text { (81.5- } \\
244.5)\end{array}$ & $\begin{array}{l}86.8(56.5- \\
149.5)\end{array}$ & $\begin{array}{l}71.7 \text { (36.6- } \\
162.4)\end{array}$ & $\begin{array}{l}1.64(1.38- \\
1.95)\end{array}$ \\
\hline $\begin{array}{l}\text { Lao People's } \\
\text { Democratic } \\
\text { Republic }\end{array}$ & 2013 & $\begin{array}{l}\text { Western } \\
\text { Pacific }\end{array}$ & 2464 & 39 & $16-65$ & 42.3 & $\begin{array}{l}118.7(72- \\
239.5)\end{array}$ & $76.4(30-130)$ & $54.2(27-103.1)$ & $\begin{array}{l}1.54(1.16- \\
1.97)\end{array}$ \\
\hline Lesotho & 2012 & Africa & 2162 & 38 & $25-64$ & 49.8 & $\begin{array}{l}126.3(77.5- \\
250)\end{array}$ & $82.6(46.5-146)$ & $\begin{array}{l}66.2(21.5- \\
164.6)\end{array}$ & $\begin{array}{l}1.61(1.02- \\
1.97)\end{array}$ \\
\hline Liberia & 2011 & Africa & 2242 & 40 & $25-64$ & 50.7 & 129 (87.5-232) & 79.8 (32-137.5) & $65.4(32-163)$ & $1.58(1-2.5)$ \\
\hline Libya & 2009 & $\begin{array}{l}\text { Eastern } \\
\text { Mediterranean }\end{array}$ & 3223 & 37 & $25-64$ & 51.5 & $\begin{array}{l}133.4(74- \\
237.5)\end{array}$ & 79.5 (44-148.5) & 77 (31.7-186.2) & $1.67(1-1.97)$ \\
\hline Myanmar & 2014 & $\begin{array}{l}\text { Southeast } \\
\text { Asia }\end{array}$ & 7892 & 42 & $25-64$ & 50.4 & $126.1(70-252)$ & $81.8(35-144)$ & $57.1(26.3-173)$ & $1.59(1-2.18)$ \\
\hline Nauru & 2016 & $\begin{array}{l}\text { Western } \\
\text { Pacific }\end{array}$ & 1037 & 36 & $18-69$ & 50 & $122.6(76-223)$ & $80.5(46.5-125)$ & $\begin{array}{l}92.4(43.4- \\
197.9)\end{array}$ & $\begin{array}{l}1.63(1.41- \\
1.86)\end{array}$ \\
\hline Niue & 2012 & $\begin{array}{l}\text { Western } \\
\text { Pacific }\end{array}$ & 779 & 40 & $15-69$ & 50.1 & 127.5 (89-223) & 75.7 (44.5-117) & $\begin{array}{l}91.5 \text { (44.7- } \\
165.9)\end{array}$ & $\begin{array}{l}1.69(1.17- \\
1.96)\end{array}$ \\
\hline Palau & 2013 & $\begin{array}{l}\text { Western } \\
\text { Pacific }\end{array}$ & 2148 & 43 & $25-64$ & 53 & $138.3(87-236)$ & $84.7(40-135)$ & $79.4(32-180.6)$ & $\begin{array}{l}1.62(1.02- \\
2.03)\end{array}$ \\
\hline Qatar & 2012 & $\begin{array}{l}\text { Eastern } \\
\text { Mediterranean }\end{array}$ & 2287 & 35 & $18-64$ & 50.9 & $\begin{array}{l}118.5(78.5- \\
203)\end{array}$ & $\begin{array}{l}78.8(46.5- \\
129.5)\end{array}$ & $\begin{array}{l}79.1(34.4- \\
190.5)\end{array}$ & $1.64(1.35-2)$ \\
\hline $\begin{array}{l}\text { Republic of } \\
\text { Moldova }\end{array}$ & 2013 & Europe & 4077 & 39 & $18-69$ & 52.5 & 132.9 (83-257) & $85.1(49-148)$ & 75 (32.5-166) & $1.68(1.2-1.98)$ \\
\hline Rwanda & 2013 & Africa & 6882 & 32 & $15-64$ & 48.8 & $120.7(75-250)$ & $77.9(45-140)$ & $57(23.1-165.8)$ & $1.6(1-1.91)$ \\
\hline Samoa & 2013 & $\begin{array}{l}\text { Western } \\
\text { Pacific }\end{array}$ & 1490 & 37 & $18-64$ & 54.1 & $\begin{array}{l}124.9(80.5- \\
221.5)\end{array}$ & $\begin{array}{l}75.3(44.5- \\
131.5)\end{array}$ & $90.3(32.1-160)$ & $\begin{array}{l}1.68(1.22- \\
1.97)\end{array}$ \\
\hline $\begin{array}{l}\text { Sao Tome and } \\
\text { Principe }\end{array}$ & 2008 & Africa & 2272 & 40 & $25-64$ & 48.4 & $\begin{array}{l}135(77.5- \\
240.5)\end{array}$ & $82.5(34.5-143)$ & $66.1(30-186.2)$ & $\begin{array}{l}1.64(1.01- \\
1.98)\end{array}$ \\
\hline Sierra Leone & 2009 & Africa & 4473 & 40 & $25-64$ & 50.3 & $131.3(72-220)$ & $80.5(42.5-148)$ & 60 (28-185) & $1.62(1-2.34)$ \\
\hline
\end{tabular}




\begin{tabular}{|c|c|c|c|c|c|c|c|c|c|c|}
\hline Sri Lanka & 2015 & $\begin{array}{l}\text { Southeast } \\
\text { Asia }\end{array}$ & 4566 & 39 & $18-69$ & 51.5 & $\begin{array}{l}125.3(74- \\
258.5)\end{array}$ & $80.6(36-150)$ & $58(26.2-156.9)$ & $1.59(1.02-1.9)$ \\
\hline Tajikistan & 2017 & Europe & 2643 & 32 & $18-69$ & 53.8 & $128.6(81-267)$ & $\begin{array}{l}84.4(54.5- \\
149.5)\end{array}$ & $66.7(27.8-148)$ & $1.63(1.09-2)$ \\
\hline Timor-Leste & 2014 & $\begin{array}{l}\text { Southeast } \\
\text { Asia }\end{array}$ & 2480 & 36 & $18-69$ & 63.8 & $\begin{array}{l}130.4(72.5- \\
235)\end{array}$ & $84(42.5-136)$ & $52(27-165)$ & $\begin{array}{l}1.57(1.24- \\
1.83)\end{array}$ \\
\hline Togo & 2011 & Africa & 3995 & 32 & $15-64$ & 49.3 & $123(70-251)$ & 76.8 (31-141.5) & $61.6(26-165)$ & $\begin{array}{l}1.64(1.02- \\
1.99)\end{array}$ \\
\hline Tuvalu & 2015 & $\begin{array}{l}\text { Western } \\
\text { Pacific }\end{array}$ & 1024 & 39 & $18-69$ & 54.9 & $\begin{array}{l}134.4(92.5- \\
246)\end{array}$ & $84.4(48.5-145)$ & $\begin{array}{l}91.9(35.8- \\
181.8) \\
\end{array}$ & $\begin{array}{l}1.68(1.17- \\
2.06)\end{array}$ \\
\hline Uganda & 2014 & Africa & 3673 & 35 & $18-69$ & 50.5 & $125(83-249)$ & $80.8(50-148)$ & $59.4(30.2-165)$ & $\begin{array}{l}1.62(1.15- \\
2.03)\end{array}$ \\
\hline $\begin{array}{l}\text { United Republic } \\
\text { of Tanzania }\end{array}$ & 2012 & Africa & 5381 & 39 & $25-64$ & 50.6 & $129.1(80-240)$ & $80.5(40-145.5)$ & $60.6(29-171.1)$ & $\begin{array}{l}1.63(1.13- \\
1.97)\end{array}$ \\
\hline Vanuatu & 2011 & $\begin{array}{l}\text { Western } \\
\text { Pacific }\end{array}$ & 4420 & 40 & $25-64$ & 47.7 & $129.6(77-269)$ & 79.6 (37.5-139) & $\begin{array}{l}69.4(28.3- \\
199.8) \\
\end{array}$ & $1.63(1.02-2.1)$ \\
\hline Vietnam & 2015 & $\begin{array}{l}\text { Western } \\
\text { Pacific }\end{array}$ & 3033 & 39 & $18-69$ & 50.4 & $120(71-223.5)$ & $77.2(40-127.5)$ & $\begin{array}{l}54.7(27.8- \\
106.4)\end{array}$ & $\begin{array}{l}1.58(1.01- \\
1.98)\end{array}$ \\
\hline
\end{tabular}


medRxiv preprint doi: https://doi.org/10.1101/2021.08.31.21262944; this version posted September 2, 2021. The copyright holder for this preprint (which was not certified by peer review) is the author/funder, who has granted medRxiv a license to display the preprint in

It is made available under a CC-BY 4.0 International license.

Supplementary Table 7. Predicted mean salt intake ( $g /$ day) by sex in each of the $\mathbf{4 9}$ national surveys included in the application of the model herein developed.

\begin{tabular}{|c|c|c|c|c|c|c|}
\hline Country & Year & Sex & $\begin{array}{l}\text { Mean salt } \\
\text { intake } \\
\text { (g/day) }\end{array}$ & $\begin{array}{l}\text { Mean salt } \\
\text { intake (g/day) } \\
\text { lower }\end{array}$ & $\begin{array}{l}\text { Mean salt } \\
\text { intake (g/day) } \\
\text { upper }\end{array}$ & Category \\
\hline Algeria & 2017 & Men & 9.43 & 9.37 & 9.48 & predicted \\
\hline Algeria & 2017 & Women & 7.72 & 7.68 & 7.76 & predicted \\
\hline Algeria & 2017 & Total & 8.6 & 8.56 & 8.64 & predicted \\
\hline American Samoa & 2004 & Men & 11.06 & 10.99 & 11.13 & predicted \\
\hline American Samoa & 2004 & Women & 9.01 & 8.95 & 9.06 & predicted \\
\hline American Samoa & 2004 & Total & 10.04 & 10 & 10.08 & predicted \\
\hline Bahamas & 2012 & Men & 10.39 & 10.21 & 10.58 & predicted \\
\hline Bahamas & 2012 & Women & 8.26 & 8.01 & 8.51 & predicted \\
\hline Bahamas & 2012 & Total & 9.33 & 9.19 & 9.46 & predicted \\
\hline Barbados & 2007 & Men & 9.61 & 9.31 & 9.92 & predicted \\
\hline Barbados & 2007 & Women & 7.86 & 7.54 & 8.18 & predicted \\
\hline Barbados & 2007 & Total & 8.77 & 8.56 & 8.98 & predicted \\
\hline Benin & 2015 & Men & 8.81 & 8.72 & 8.91 & predicted \\
\hline Benin & 2015 & Women & 7.29 & 7.2 & 7.37 & predicted \\
\hline Benin & 2015 & Total & 8.04 & 7.92 & 8.16 & predicted \\
\hline Botswana & 2014 & Men & 8.61 & 8.54 & 8.69 & predicted \\
\hline Botswana & 2014 & Women & 7.39 & 7.34 & 7.45 & predicted \\
\hline Botswana & 2014 & Total & 8.03 & 7.97 & 8.09 & predicted \\
\hline $\begin{array}{l}\text { British Virgin } \\
\text { Islands }\end{array}$ & 2009 & Men & 10.09 & 10.03 & 10.16 & predicted \\
\hline $\begin{array}{l}\text { British Virgin } \\
\text { Islands }\end{array}$ & 2009 & Women & 8.02 & 8.01 & 8.02 & predicted \\
\hline $\begin{array}{l}\text { British Virgin } \\
\text { Islands }\end{array}$ & 2009 & Total & 9.14 & 9.08 & 9.2 & predicted \\
\hline Cabo Verde & 2007 & Men & 9.13 & 9 & 9.25 & predicted \\
\hline Cabo Verde & 2007 & Women & 7.46 & 7.36 & 7.55 & predicted \\
\hline Cabo Verde & 2007 & Total & 8.3 & 8.19 & 8.41 & predicted \\
\hline Cambodia & 2010 & Men & 8.7 & 8.66 & 8.75 & predicted \\
\hline Cambodia & 2010 & Women & 7.23 & 7.2 & 7.25 & predicted \\
\hline Cambodia & 2010 & Total & 7.96 & 7.92 & 7.99 & predicted \\
\hline Cayman Islands & 2012 & Men & 9.95 & 9.89 & 10 & predicted \\
\hline Cayman Islands & 2012 & Women & 8.08 & 7.86 & 8.29 & predicted \\
\hline Cayman Islands & 2012 & Total & 9.03 & 8.96 & 9.09 & predicted \\
\hline Comoros & 2011 & Men & 9.09 & 9.04 & 9.15 & predicted \\
\hline
\end{tabular}


medRxiv preprint doi: https://doi.org/10.1101/2021.08.31.21262944; this version posted September 2, 2021. The copyright holder for this preprint (which was not certified by peer review) is the author/funder, who has granted medRxiv a license to display the preprint in

It is made available under a CC-BY 4.0 International license.

\begin{tabular}{|c|c|c|c|c|c|c|}
\hline Comoros & 2011 & Women & 7.74 & 7.7 & 7.78 & predictec \\
\hline Comoros & 2011 & Total & 8.45 & 8.4 & 8.5 & predictec \\
\hline Cook Islands & 2015 & Men & 11.02 & 10.95 & 11.1 & predictec \\
\hline Cook Islands & 2015 & Women & 8.63 & 8.56 & 8.69 & predictec \\
\hline Cook Islands & 2015 & Total & 9.74 & 9.64 & 9.84 & predictec \\
\hline Ecuador & 2018 & Men & 9.74 & 9.67 & 9.81 & predictec \\
\hline Ecuador & 2018 & Women & 7.8 & 7.75 & 7.84 & predictec \\
\hline Ecuador & 2018 & Total & 8.76 & 8.68 & 8.83 & predictec \\
\hline Eritrea & 2010 & Men & 8.4 & 8.34 & 8.47 & predictec \\
\hline Eritrea & 2010 & Women & 6.93 & 6.89 & 6.97 & predictec \\
\hline Eritrea & 2010 & Total & 7.18 & 7.14 & 7.22 & predictec \\
\hline Eswatini & 2014 & Men & 9.01 & 8.9 & 9.12 & predictec \\
\hline Eswatini & 2014 & Women & 7.71 & 7.65 & 7.77 & predictec \\
\hline Eswatini & 2014 & Total & 8.33 & 8.26 & 8.39 & predictec \\
\hline Ethiopia & 2015 & Men & 8.28 & 8.24 & 8.32 & predictec \\
\hline Ethiopia & 2015 & Women & 6.92 & 6.89 & 6.95 & predictec \\
\hline Ethiopia & 2015 & Total & 7.69 & 7.65 & 7.72 & predictec \\
\hline Fiji & 2011 & Men & 9.75 & 9.63 & 9.86 & predictec \\
\hline Fiji & 2011 & Women & 8.02 & 7.95 & 8.08 & predictec \\
\hline Fiji & 2011 & Total & 8.9 & 8.79 & 9.01 & predictec \\
\hline French Polynesia & 2010 & Men & 10.24 & 10.13 & 10.35 & predictec \\
\hline French Polynesia & 2010 & Women & 8.04 & 7.95 & 8.13 & predictec \\
\hline French Polynesia & 2010 & Total & 9.16 & 9.06 & 9.25 & predictec \\
\hline Gambia & 2010 & Men & 9.1 & 8.96 & 9.24 & predictec \\
\hline Gambia & 2010 & Women & 7.54 & 7.46 & 7.62 & predictec \\
\hline Gambia & 2010 & Total & 8.33 & 8.22 & 8.43 & predictec \\
\hline Grenada & 2011 & Men & 9.49 & 9.39 & 9.59 & predictec \\
\hline Grenada & 2011 & Women & 7.89 & 7.8 & 7.98 & predictec \\
\hline Grenada & 2011 & Total & 8.7 & 8.61 & 8.79 & predictec \\
\hline Guyana & 2016 & Men & 9.28 & 9.17 & 9.39 & predictec \\
\hline Guyana & 2016 & Women & 7.85 & 7.78 & 7.92 & predictec \\
\hline Guyana & 2016 & Total & 8.59 & 8.53 & 8.66 & predictec \\
\hline Iraq & 2015 & Men & 9.73 & 9.63 & 9.84 & predictec \\
\hline Iraq & 2015 & Women & 8.01 & 7.95 & 8.07 & predictec \\
\hline Iraq & 2015 & Total & 8.94 & 8.86 & 9.01 & predictec \\
\hline Kenya & 2015 & Men & 8.69 & 8.59 & 8.78 & predictec \\
\hline Kenya & 2015 & Women & 7.35 & 7.27 & 7.42 & predictec \\
\hline Kenya & 2015 & Total & 8.02 & 7.94 & 8.11 & predictec \\
\hline
\end{tabular}


medRxiv preprint doi: https://doi.org/10.1101/2021.08.31.21262944; this version posted September 2, 2021. The copyright holder for this preprint (which was not certified by peer review) is the author/funder, who has granted medRxiv a license to display the preprint in

It is made available under a CC-BY 4.0 International license.

\begin{tabular}{|c|c|c|c|c|c|c|}
\hline Kiribati & 2016 & Men & 10.19 & 9.99 & 10.39 & predicted \\
\hline Kiribati & 2016 & Women & 8.25 & 8.14 & 8.36 & predicted \\
\hline Kiribati & 2016 & Total & 9.08 & 8.94 & 9.23 & predicted \\
\hline Kuwait & 2014 & Men & 10.19 & 10.11 & 10.26 & predicted \\
\hline Kuwait & 2014 & Women & 8.08 & 8.03 & 8.13 & predicted \\
\hline Kuwait & 2014 & Total & 9.13 & 9.07 & 9.18 & predicted \\
\hline Kyrgyzstan & 2013 & Men & 9.58 & 9.43 & 9.73 & predicted \\
\hline Kyrgyzstan & 2013 & Women & 7.8 & 7.75 & 7.85 & predicted \\
\hline Kyrgyzstan & 2013 & Total & 8.72 & 8.65 & 8.8 & predicted \\
\hline $\begin{array}{l}\text { Lao People's } \\
\text { Democratic } \\
\text { Republic }\end{array}$ & 2013 & Men & 8.97 & 8.88 & 9.05 & predicted \\
\hline $\begin{array}{l}\text { Lao People's } \\
\text { Democratic } \\
\text { Republic }\end{array}$ & 2013 & Women & 7.38 & 7.32 & 7.43 & predicted \\
\hline $\begin{array}{l}\text { Lao People's } \\
\text { Democratic } \\
\text { Republic }\end{array}$ & 2013 & Total & 8.05 & 7.98 & 8.12 & predicted \\
\hline Lesotho & 2012 & Men & 9.01 & 8.9 & 9.11 & predicted \\
\hline Lesotho & 2012 & Women & 7.92 & 7.83 & 8 & predicted \\
\hline Lesotho & 2012 & Total & 8.46 & 8.38 & 8.54 & predicted \\
\hline Liberia & 2011 & Men & 9.52 & 9.38 & 9.65 & predicted \\
\hline Liberia & 2011 & Women & 7.93 & 7.82 & 8.05 & predicted \\
\hline Liberia & 2011 & Total & 8.74 & 8.61 & 8.87 & predicted \\
\hline Libya & 2009 & Men & 9.67 & 9.59 & 9.75 & predicted \\
\hline Libya & 2009 & Women & 8.07 & 8 & 8.14 & predicted \\
\hline Libya & 2009 & Total & 8.89 & 8.83 & 8.95 & predicted \\
\hline Myanmar & 2014 & Men & 8.71 & 8.59 & 8.82 & predicted \\
\hline Myanmar & 2014 & Women & 7.41 & 7.32 & 7.49 & predicted \\
\hline Myanmar & 2014 & Total & 8.06 & 7.98 & 8.14 & predicted \\
\hline Nauru & 2016 & Men & 11.11 & 11.01 & 11.2 & predicted \\
\hline Nauru & 2016 & Women & 8.76 & 8.6 & 8.92 & predicted \\
\hline Nauru & 2016 & Total & 9.93 & 9.8 & 10.06 & predicted \\
\hline Niue & 2012 & Men & 10.73 & 10.61 & 10.85 & predicted \\
\hline Niue & 2012 & Women & 8.33 & 8.21 & 8.44 & predicted \\
\hline Niue & 2012 & Total & 9.53 & 9.41 & 9.65 & predicted \\
\hline Palau & 2013 & Men & 10.52 & 10.4 & 10.65 & predicted \\
\hline Palau & 2013 & Women & 8.19 & 8.12 & 8.26 & predicted \\
\hline Palau & 2013 & Total & 9.43 & 9.33 & 9.53 & predicted \\
\hline Qatar & 2012 & Men & 10.17 & 10.06 & 10.29 & predicted \\
\hline
\end{tabular}


medRxiv preprint doi: https://doi.org/10.1101/2021.08.31.21262944; this version posted September 2, 2021. The copyright holder for this preprint (which was not certified by peer review) is the author/funder, who has granted medRxiv a license to display the preprint in

It is made available under a CC-BY 4.0 International license.

\begin{tabular}{|c|c|c|c|c|c|c|}
\hline Qatar & 2012 & Women & 8.11 & 8.01 & 8.21 & predictec \\
\hline Qatar & 2012 & Total & 9.16 & 9.06 & 9.26 & predictec \\
\hline $\begin{array}{l}\text { Republic of } \\
\text { Moldova }\end{array}$ & 2013 & Men & 9.64 & 9.56 & 9.72 & predictec \\
\hline $\begin{array}{l}\text { Republic of } \\
\text { Moldova }\end{array}$ & 2013 & Women & 7.56 & 7.5 & 7.62 & predictec \\
\hline $\begin{array}{l}\text { Republic of } \\
\text { Moldova }\end{array}$ & 2013 & Total & 8.65 & 8.59 & 8.72 & predictec \\
\hline Rwanda & 2013 & Men & 8.67 & 8.63 & 8.7 & predictec \\
\hline Rwanda & 2013 & Women & 7.29 & 7.26 & 7.32 & predictec \\
\hline Rwanda & 2013 & Total & 7.96 & 7.93 & 7.99 & predictec \\
\hline Samoa & 2013 & Men & 10.44 & 10.3 & 10.58 & predictec \\
\hline Samoa & 2013 & Women & 8.63 & 8.56 & 8.7 & predictec \\
\hline Samoa & 2013 & Total & 9.61 & 9.51 & 9.7 & predictec \\
\hline $\begin{array}{l}\text { Sao Tome and } \\
\text { Principe } \\
\end{array}$ & 2008 & Men & 9.11 & 9.07 & 9.15 & predictec \\
\hline $\begin{array}{l}\text { Sao Tome and } \\
\text { Principe } \\
\end{array}$ & 2008 & Women & 7.54 & 7.44 & 7.64 & predictec \\
\hline $\begin{array}{l}\text { Sao Tome and } \\
\text { Principe }\end{array}$ & 2008 & Total & 8.3 & 8.22 & 8.38 & predictec \\
\hline Sierra Leone & 2009 & Men & 8.83 & 8.73 & 8.93 & predictec \\
\hline Sierra Leone & 2009 & Women & 7.41 & 7.32 & 7.51 & predictec \\
\hline Sierra Leone & 2009 & Total & 8.13 & 8.03 & 8.23 & predictec \\
\hline Sri Lanka & 2015 & Men & 8.82 & 8.75 & 8.89 & predictec \\
\hline Sri Lanka & 2015 & Women & 7.29 & 7.25 & 7.33 & predictec \\
\hline Sri Lanka & 2015 & Total & 8.08 & 8.03 & 8.13 & predictec \\
\hline Tajikistan & 2017 & Men & 9.4 & 9.3 & 9.5 & predictec \\
\hline Tajikistan & 2017 & Women & 7.55 & 7.48 & 7.62 & predictec \\
\hline Tajikistan & 2017 & Total & 8.55 & 8.46 & 8.64 & predictec \\
\hline Timor-Leste & 2014 & Men & 8.42 & 8.37 & 8.46 & predictec \\
\hline Timor-Leste & 2014 & Women & 7 & 6.88 & 7.11 & predictec \\
\hline Timor-Leste & 2014 & Total & 7.9 & 7.8 & 8 & predictec \\
\hline Togo & 2011 & Men & 8.71 & 8.66 & 8.77 & predictec \\
\hline Togo & 2011 & Women & 7.21 & 7.16 & 7.26 & predictec \\
\hline Togo & 2011 & Total & 7.95 & 7.9 & 8 & predictec \\
\hline Tuvalu & 2015 & Men & 10.57 & 10.44 & 10.71 & predictec \\
\hline Tuvalu & 2015 & Women & 8.59 & 8.5 & 8.68 & predictec \\
\hline Tuvalu & 2015 & Total & 9.68 & 9.57 & 9.79 & predictec \\
\hline Uganda & 2014 & Men & 8.63 & 8.57 & 8.69 & predictec \\
\hline Uganda & 2014 & Women & 7.22 & 7.16 & 7.28 & predictec \\
\hline
\end{tabular}


medRxiv preprint doi: https://doi.org/10.1101/2021.08.31.21262944; this version posted September 2,2021 . The copyright holder for this preprint (which was not certified by peer review) is the author/funder, who has granted medRxiv a license to display the preprint in It is made available under a CC-BY 4.0 International license.

\begin{tabular}{|l|l|l|l|l|l|l|}
\hline Uganda & 2014 & Total & 7.93 & 7.87 & 7.99 & predicted \\
\hline $\begin{array}{l}\text { United Republic of } \\
\text { Tanzania }\end{array}$ & 2012 & Men & 8.6 & 8.47 & 8.72 & predicted \\
\hline $\begin{array}{l}\text { United Republic of } \\
\text { Tanzania }\end{array}$ & 2012 & Women & 7.48 & 7.41 & 7.55 & predicted \\
\hline $\begin{array}{l}\text { United Republic of } \\
\text { Tanzania }\end{array}$ & 2012 & Total & 8.04 & 7.98 & 8.11 & predicted \\
\hline Vanuatu & 2011 & Men & 9.52 & 9.44 & 9.59 & predicted \\
\hline Vanuatu & 2011 & Women & 7.75 & 7.69 & 7.81 & predicted \\
\hline Vanuatu & 2011 & Total & 8.59 & 8.53 & 8.66 & predicted \\
\hline Vietnam & 2015 & Men & 8.75 & 8.68 & 8.82 & predicted \\
\hline Vietnam & 2015 & Women & 7.11 & 7.07 & 7.16 & predicted \\
\hline Vietnam & 2015 & Total & 7.94 & 7.88 & 8 & predicted \\
\hline
\end{tabular}


medRxiv preprint doi: https://doi.org/10.1101/2021.08.31.21262944; this version posted September 2, 2021. The copyright holder for this preprint (which was not certified by peer review) is the author/funder, who has granted medRxiv a license to display the preprint in It is made available under a CC-BY 4.0 International license.

Supplementary Table 8. Comparison between mean salt intake predictions and global estimates across national surveys included in the ML application.

\begin{tabular}{|c|c|c|c|c|c|c|}
\hline Country & \begin{tabular}{|l|} 
Year (for \\
ML \\
predictions)
\end{tabular} & \begin{tabular}{|l} 
ML- \\
predicted \\
mean salt \\
intake and \\
$95 \% \mathrm{Cl}$ \\
(g/day)
\end{tabular} & $\begin{array}{l}\text { Year (for } \\
\text { global } \\
\text { estimatates) }\end{array}$ & $\begin{array}{l}\text { Estimated } \\
\text { mean salt } \\
\text { intake and } \\
95 \% \mathrm{Cl} \\
\text { (g/day) }\end{array}$ & $\begin{array}{l}\text { Ratio } \\
\text { between } \\
\text { predicted } \\
\text { and } \\
\text { estimated } \\
\text { mean salt } \\
\text { intake }\end{array}$ & \begin{tabular}{|l} 
Absolute \\
difference \\
between \\
predicted \\
mean salt \\
intake and \\
global \\
estimated \\
mean salt \\
intake
\end{tabular} \\
\hline Algeria & 2017 & \begin{tabular}{|l}
$8.6(8.6-$ \\
$8.6)$
\end{tabular} & 2010 & \begin{tabular}{|l}
$10.7(9-$ \\
$12.5)$
\end{tabular} & 0.8 & 2.1 \\
\hline Bahamas & 2012 & $\begin{array}{l}9.3 \text { (9.2- } \\
9.5)\end{array}$ & 2010 & $7.5(6.2-8.8)$ & 1.2 & 1.8 \\
\hline Barbados & 2007 & $8.8(8.6-9)$ & 2010 & $8.6(7.8-9.4)$ & 1 & 0.2 \\
\hline Benin & 2015 & 8 (7.9-8.2) & 2010 & $7.1(6.2-8.1)$ & 1.1 & 0.9 \\
\hline Botswana & 2014 & $8(8-8.1)$ & 2010 & $6.3(5.4-7.4)$ & 1.3 & 1.7 \\
\hline Cabo Verde & 2007 & $\begin{array}{l}8.3(8.2- \\
8.4)\end{array}$ & 2010 & $8.1(6.8-9.7)$ & 1 & 0.2 \\
\hline Cambodia & 2010 & $8(7.9-8)$ & 2010 & $\begin{array}{l}11(9.3- \\
12.9)\end{array}$ & 0.7 & 3 \\
\hline Comoros & 2011 & \begin{tabular}{|l}
$8.4(8.4-$ \\
$8.5)$
\end{tabular} & 2010 & $4.2(3.5-5)$ & 2 & 4.2 \\
\hline Ecuador & 2018 & $\begin{array}{l}8.8(8.7- \\
8.8)\end{array}$ & 2010 & $7.6(6.4-8.9)$ & 1.2 & 1.2 \\
\hline Eritrea & 2010 & $\begin{array}{l}7.2(7.1- \\
7.2)\end{array}$ & 2010 & $5.9(5-7)$ & 1.2 & 1.3 \\
\hline Ethiopia & 2015 & $\begin{array}{l}7.7(7.7- \\
7.7)\end{array}$ & 2010 & $5.7(4.9-6.7)$ & 1.4 & 2 \\
\hline$F i j i$ & 2011 & $8.9(8.8-9)$ & 2010 & $7.2(6-8.5)$ & 1.2 & 1.7 \\
\hline Gambia & 2010 & $\begin{array}{l}8.3(8.2- \\
8.4)\end{array}$ & 2010 & $7.7(6.5-8.9)$ & 1.1 & 0.6 \\
\hline Grenada & 2011 & \begin{tabular}{|l}
8.7 (8.6- \\
$8.8)$
\end{tabular} & 2010 & $6.5(5.5-7.7)$ & 1.3 & 2.2 \\
\hline Guyana & 2016 & \begin{tabular}{|l}
$8.6(8.5-$ \\
$8.7)$
\end{tabular} & 2010 & $6.1(5.1-7.3)$ & 1.4 & 2.5 \\
\hline Iraq & 2015 & 8.9 (8.9-9) & 2010 & $9.4(8-11.2)$ & 0.9 & 0.5 \\
\hline Kenya & 2015 & 8 (7.9-8.1) & 2010 & $3.7(3.4-4)$ & 2.2 & 4.3 \\
\hline Kiribati & 2016 & \begin{tabular}{|l}
9.1 (8.9- \\
$9.2)$
\end{tabular} & 2010 & $5.6(4.6-6.7)$ & 1.6 & 3.5 \\
\hline Kuwait & 2014 & $\begin{array}{l}9.1(9.1- \\
9.2)\end{array}$ & 2010 & \begin{tabular}{|l|}
$9.7(8.7-$ \\
$10.8)$
\end{tabular} & 0.9 & 0.6 \\
\hline Kyrgyzstan & 2013 & $\begin{array}{l}8.7(8.7- \\
8.8)\end{array}$ & 2010 & \begin{tabular}{|l|}
$13.4(11.4-$ \\
$15.8)$
\end{tabular} & 0.6 & 4.7 \\
\hline
\end{tabular}


medRxiv preprint doi: https://doi.org/10.1101/2021.08.31.21262944; this version posted September 2, 2021. The copyright holder for this preprint (which was not certified by peer review) is the author/funder, who has granted medRxiv a license to display the preprint in It is made available under a CC-BY 4.0 International license.

\begin{tabular}{|c|c|c|c|c|c|c|}
\hline $\begin{array}{l}\text { Lao People's } \\
\text { Democratic } \\
\text { Republic }\end{array}$ & 2013 & $8.1(8-8.1)$ & 2010 & $\begin{array}{l}11.1(9.4- \\
13.2)\end{array}$ & 0.7 & 3 \\
\hline Lesotho & 2012 & $\begin{array}{l}8.5(8.4- \\
8.5)\end{array}$ & 2010 & $6.6(5.5-7.8)$ & 1.3 & 1.9 \\
\hline Liberia & 2011 & $\begin{array}{l}8.7 \text { (8.6- } \\
8.9)\end{array}$ & 2010 & $6.7(5.6-7.9)$ & 1.3 & 2 \\
\hline Libya & 2009 & $\begin{array}{l}8.9(8.8- \\
8.9)\end{array}$ & 2010 & $\begin{array}{l}10.6(8.9- \\
12.5)\end{array}$ & 0.8 & 1.7 \\
\hline Myanmar & 2014 & $8.1(8-8.1)$ & 2010 & $\begin{array}{l}11.2(9.4- \\
13.2)\end{array}$ & 0.7 & 3.1 \\
\hline Qatar & 2012 & $\begin{array}{l}9.2(9.1- \\
9.3)\end{array}$ & 2010 & $\begin{array}{l}10.5(8.3- \\
12.9)\end{array}$ & 0.9 & 1.3 \\
\hline $\begin{array}{l}\text { Republic of } \\
\text { Moldova }\end{array}$ & 2013 & $\begin{array}{l}8.7(8.6- \\
8.7)\end{array}$ & 2010 & $\begin{array}{l}9.9(8.3- \\
11.6)\end{array}$ & 0.9 & 1.2 \\
\hline Rwanda & 2013 & 8 (7.9-8) & 2010 & 4 (3.3-4.9) & 2 & 4 \\
\hline Samoa & 2013 & $\begin{array}{l}9.6(9.5- \\
9.7)\end{array}$ & 2010 & $5.2(4.6-5.8)$ & 1.8 & 4.4 \\
\hline $\begin{array}{l}\text { Sao Tome } \\
\text { and Principe }\end{array}$ & 2008 & \begin{tabular}{|l}
$8.3(8.2-$ \\
$8.4)$
\end{tabular} & 2010 & $5.9(4.9-6.9)$ & 1.4 & 2.4 \\
\hline Sierra Leone & 2009 & $8.1(8-8.2)$ & 2010 & $6.3(5.3-7.3)$ & 1.3 & 1.8 \\
\hline Sri Lanka & 2015 & $8.1(8-8.1)$ & 2010 & \begin{tabular}{|l}
$9.7(8.2-$ \\
$11.3)$
\end{tabular} & 0.8 & 1.6 \\
\hline Tajikistan & 2017 & \begin{tabular}{|l}
$8.6(8.5-$ \\
$8.6)$
\end{tabular} & 2010 & $\begin{array}{l}13.5(11.6- \\
15.7)\end{array}$ & 0.6 & 4.9 \\
\hline Timor-Leste & 2014 & $7.9(7.8-8)$ & 2010 & $\begin{array}{l}11.2(9.3- \\
13.3)\end{array}$ & 0.7 & 3.3 \\
\hline Uganda & 2014 & $7.9(7.9-8)$ & 2010 & $5.3(4.4-6.3)$ & 1.5 & 2.6 \\
\hline \begin{tabular}{|l} 
United \\
Republic of \\
Tanzania
\end{tabular} & 2012 & $8(8-8.1)$ & 2010 & $6.9(6.1-7.7)$ & 1.2 & 1.1 \\
\hline Vanuatu & 2011 & $\begin{array}{l}8.6(8.5- \\
8.7)\end{array}$ & 2010 & $5.6(4.8-6.6)$ & 1.5 & 3 \\
\hline Vietnam & 2015 & 7.9 (7.9-8) & 2010 & $\begin{array}{l}11.5(9.5- \\
13.7)\end{array}$ & 0.7 & 3.6 \\
\hline
\end{tabular}

${ }^{*}$ There are 38 countries in this table; that is, countries included in our analysis that were not available in the previous global work, were not included in this table.

Reference: Powles J, Fahimi S, Micha R, Khatibzadeh S, Shi P, Ezzati M, et al. Global, regional and national sodium intakes in 1990 and 2010: a systematic analysis of $24 \mathrm{~h}$ urinary sodium excretion and dietary surveys worldwide. BMJ Open. 2013 Dec 23;3(12):e003733. 
medRxiv preprint doi: https://doi.org/10.1101/2021.08.31.21262944; this version posted September 2, 2021. The copyright holder for this preprint (which was not certified by peer review) is the author/funder, who has granted medRxiv a license to display the preprint in It is made available under a CC-BY 4.0 International license.

Supplementary Figure 2. Comparison between mean difference between observed and predicted salt intake across the best algorithms 
